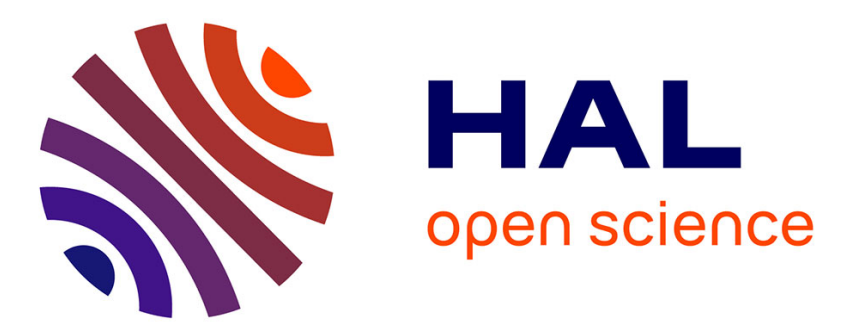

\title{
The influence of price and non-price effects on demand for heating in the EU residential sector
}

Eoin Ó Broin, Jonas Nässén, Filip Johnsson

\section{To cite this version:}

Eoin Ó Broin, Jonas Nässén, Filip Johnsson. The influence of price and non-price effects on demand for heating in the EU residential sector. Energy, 2015, 81, pp.146-158. 10.1016/j.energy.2014.12.003 . hal-01219278v2

\section{HAL Id: hal-01219278 \\ https://hal.science/hal-01219278v2}

Submitted on 18 Jan 2017

HAL is a multi-disciplinary open access archive for the deposit and dissemination of scientific research documents, whether they are published or not. The documents may come from teaching and research institutions in France or abroad, or from public or private research centers.
L'archive ouverte pluridisciplinaire HAL, est destinée au dépôt et à la diffusion de documents scientifiques de niveau recherche, publiés ou non, émanant des établissements d'enseignement et de recherche français ou étrangers, des laboratoires publics ou privés. 
TITLE:

The influence of price and non-price effects on demand for heating in the EU residential sector

CORRESPONDING AUTHOR FAMILY NAME:

Ó Broin ${ }^{\mathrm{a}}$

\section{CORRESPONDING AUTHOR FIRST NAME:}

Eoin

e-mail: $\quad$ eoin.obroin@chalmers.se

Phone: $\quad+46317721450$

Fax: $\quad+46317723592$

CO-AUTHOR 1:

Jonas Nässén ${ }^{\mathrm{b}}$

e-mail: jonas.nassen@chalmers.se

CO-AUTHOR 2:

Filip Johnsson ${ }^{\mathrm{a}}$

e-mail: filip.johnsson@chalmers.se

${ }^{a}$ Department of Energy and Environment, Energy Technology,

Chalmers University of Technology,

SE-412 96 Göteborg

${ }^{b}$ Department of Energy and Environment, Physical Resource Theory,

Chalmers University of Technology,

SE-412 96 Göteborg 


\title{
The influence of price and non-price effects on demand for heating in the EU residential sector
}

\begin{abstract}
This paper models energy demand for space and water heating from 1970 to 2005 in the residential sector of four EU countries (France, Italy, Sweden, and UK) using index decomposition, ARDL econometric models and cointegration analysis. The partial and temporal influences on energy demand in each country of the number of households, floor area per household $\left(\mathrm{m}^{2}\right)$ and unit consumption for space and water heating $\left(\mathrm{kWh} / \mathrm{m}^{2} /\right.$ year $)$ are disaggregated. The long-run price elasticity of demand at the unit consumption level is found to be low (around -0.25 over the four countries) while the long-run income elasticity of floor area per household is found to be around 0.25 for Italy, Sweden and the UK but insignificant for France. In an exercise using the model to estimate demand to 2050 under annual increases in energy prices of between $0 \%$ and $3 \%$ it is found that non-price effects such as building codes and autonomous technical progress (represented in the model as a time trend) are equally or more important than the price effect in reducing demand. Thus achieving significant reductions in EU residential sector energy demand by 2050 would require additional non-price policies and measures for success.
\end{abstract}

\section{Keywords}

Heating, Residential, Scenarios, Price and non-price effects

\section{INTRODUCTION}

Energy use in buildings accounted for over $40 \%$ of primary energy use in the EU in 2005 . The full cost-effective potential for energy savings from efficiency by 2020 in this sector is estimated to be between $27 \%$ and $30 \%$ [1]. Achieving this potential is part of the EU Climate and Energy Packet (known colloquially as the EU 202020 goal), which proposes that by 2020 that there should be a $20 \%$ saving in primary energy use (relative to a projected value), a $20 \%$ share for renewables in the energy supply, and a $20 \%$ reduction in greenhouse gas emissions (relative to the levels in 1990) [2]. Achieving these targets would help the EU contribute to limiting anthropogenic global warming to a maximum of $2^{\circ} \mathrm{C}$, which is the target adopted by the EU based on the scientific evidence on global warming highlighted by the IPCC. Understanding the effects of energy prices and taxes and other aggregate determinants of 
energy demand up to and after 2020 is important in determining whether these EU political goals can realistically be achieved.

An extensive literature using econometrics to examine energy demand in the residential sector exists, although it is mostly focused on the electricity component of this demand. A comprehensive review of US focused studies has been carried out [3] and describes lagged endogenous models as being the most ubiquitous models observed in the literature for separating out the short and long run effects on demand for energy services. A survey of various econometric approaches to modelling residential energy demand and how the methodologies have evolved is provided [4]. Relevant publications up to 2010 have been summarised [5] and the authors write that since the beginning of 1990s, that cointegration analysis has become the standard component of all studies using time series data. In this regard a pioneering cointegration analyses work is [6] where the use of an Error Correction Model (ECM) to calculate the short- and long-term price elasticities of energy demand in Denmark is demonstrated. The same authors cite [7] to update their 1993 work [8] to show that the Autoregressive Distributed Lag model (ARDL) can be used for the same purposes as long as the underlying variables are cointegrated.

While using econometric models as the previous authors do to model the historic development of energy demand, is a well-established science, there is less acceptance on the use of such models for forecasting energy demand. A comprehensive critique is given [9] arguing that it is a mistake to assume that the future will replicate the past. In the same vein it is suggested [10] that using econometric models for energy demand forecasting should be restricted to 5 to 10 years into the future because such models cannot account for structural changes which are inevitable over longer time periods. For forecasting over longer time periods they suggest the disaggregation of energy demand into structural components of the economy e.g. demographics, and the creation of scenarios for their development. In their approach, econometrics can be used to model the long-term development of homogenous individual structural components of the economy e.g. energy efficiency.

Useful methods of disaggregating energy demand (Index decomposition) into the historical temporal partial influences of energy efficiency, changes in floor area, and numbers of households on total energy demand have been shown $[11,12]$. Such disaggregation's are also useful for choosing the structural components of energy demand to use in the scenario modelling approach suggested by [10]. Econometrics are specifically used to model the role 
of energy efficiency in explaining demand in the residential sector [13-15]. Their contributions are important in light of the often cited potential of energy efficiency to vastly reduce demand in the sector.

The present study uses cointegration analysis, ARDL and index decomposition (ID) to model how energy demand for space and water heating has developed since the 1970's in the residential sectors of four EU countries. Traditionally modelling demand for space and water heating has not been possible because of a lack of data. The advent of the Odyssee Database [16] has however changed this situation for the EU. In addition, as space heating typically represents over $60 \%$ of demand in the residential sector in EU countries, its analysis is well warranted. The countries modelled (France, Italy, UK, and Sweden) are chosen because of the availability of relevant data extending back to 1970 's, their diversity in terms of climate and the degrees of housing insulation, and the fact that the first three countries listed account for approximately $40 \%$ of the total energy demand of the EU residential sector. The modelling is carried out for the countries individually rather than by grouping them in a panel (as carried out by [15]) in order to be able to compare results across countries. The work focuses on aggregate demand for heat (the sum of all energy carriers) rather than the individual energy carriers which would require the calculation of cross - price elasticities and significantly more data manipulation and assumptions on future prices of individual energy carriers. Heat demand itself has been more stable since the 1970's thus making it easier to model as opposed to different energy carriers which have changed over the period, e.g. natural gas heating has replaced oil heating as the dominant heating energy carrier in many EU countries.

The aim of the paper is to elucidate the parameters affecting the demand for space and water heating in the four countries. The methodology applied is intentionally top-down so as to allow for an analysis of the price and income and other aggregated drivers of energy demand. This exact methodologies employed are gleaned from the papers cited above. The work augments that of $[13,14]$ by including cointegration analysis, extending the time series used to 2005 and using the model to make scenarios of future energy demand to 2050. Making use of a top-down model to compare results to EU Energy policy aspirations is also a unique feature of the paper. The use of ID allows the influences of energy efficiency, changes in floor area, and numbers of households on total energy demand to be analysed individually. This follows the approach of modelling structural components of energy demand as suggested by [10] and also allows for the long-term estimation of how demand may develop to 2050.The purpose 
with making long-term energy demand scenarios to 2050 is to show the partial effect of the drivers of energy demand to provide insights for policy makers rather than any attempt to estimate what will happen.

The paper is organised as follows: The methodology section provides a description of the decomposition analysis, the econometric model used, and the data series investigated. The results section begins with the decomposition of the trend in total energy demand, followed by econometric results to explain the trends in floor area and unit consumption (measured in $\mathrm{kWh} / \mathrm{m}^{2} / \mathrm{yr}$ ). These results are then used to make a set of scenarios to 2050 based on developments in energy prices. Finally, the results are discussed from the perspectives of energy policy, and conclusions are drawn.

\section{$2 \quad$ METHODOLOGY}

\section{$2.1 \quad$ Modelling}

The total demand for energy for space and water heating, $E_{t}$ (in TWh), is divided into three sub-components [12], as follows:

$$
E_{t}=A_{t} S_{t} I_{t}
$$

where $A$ is the number of households in millions, $S$ is the residential sector floor area per household (in $\mathrm{m}^{2} /$ household), $I$ is the unit consumption for energy demand for space heating per year (measured in $\mathrm{kWh} / \mathrm{m}^{2} / \mathrm{yr}$ ) and $t$ is time (in years).

Log mean divisia index decomposition (LMDI) [11] is used to visualise the temporal partial influences of $A, S$, and $I$ on $E$. The three parameters $A_{t}, S_{t}$, and $I_{t}$ are modelled individually. The number of households $A_{t}$ is obtained by dividing the population by the number of persons per household. For the floor area per household ${ }^{1} S_{t}$, and the unit consumption for space and water heating $I_{t}$, econometric modelling is carried out. Future scenarios for population, income per capita, and energy prices are then used as inputs to establish the projected values of $A_{t}, S_{t}$, and $I_{t}$.

\footnotetext{
${ }^{1}$ Floor area per household approximates floor area per dwelling as the number of households is approximately equal to the number of permanently occupied dwellings [16].
} 


\section{$2.2 \quad$ Econometric Models}

A general ARDL model of energy demand where real income, real energy prices and heating degree days are the explanatory variables has been presented [8]. This present work modifies the Bentzen and Engsteds ARDL model to make $I_{t}$ from Equation (1) the dependant variable. In addition income is dropped and absolute values of heating degree days are used so as to model the influence of a degree day change ${ }^{2}$. Income is not included as an explanatory variable as the dependant variable has been normalised to a unit of floor area. The exponential time trend coefficient is assumed to represent various factors, such as autonomous technological development, imposition of regulations, and other variables not captured by price, lag, and heating degree days. The modified Bentzen and Engsteds ARDL model then becomes a model of Unit Consumption and is presented in Equation (2) where $I_{t}, P_{t}$ and $H D D_{t}$ are the absolute values of energy demand, energy prices and heating degree days respectively:

$$
\ln \left(I_{t}\right)=\alpha_{0}+\alpha_{1}(t)+\sum_{i=1}^{p} \Phi_{i} \ln \left(I_{t-i}\right)+\sum_{i=1}^{q} \beta_{2 i} \ln \left(P_{t-i}\right)+\sum_{i=1}^{q} \beta_{3 i}\left(H D D_{t-i}\right)+e_{t}
$$

The income variable, $Y_{t}$, removed from the Bentzen and Engsteds ARDL model is then introduced in the following model of floor area per household ( $S$ from Equation 1$)$ because it is assumed to have a greater correlation with floor area growth than with unit consumption :

$$
\ln \left(S_{t}\right)=\gamma_{0}+\sum_{i=1}^{p} \lambda_{i} \ln \left(S_{t-1}\right)+\sum_{i=1}^{q} \beta_{1 i} \ln \left(Y_{t-i}\right)+e_{t}
$$

Demographic change, for example an increasing share of old people, could potentially influence the development of both floor area and energy use. Data to support a thorough analysis of demographic change is, however, not available. As is standard with ARDL models the value of the long-run income elasticity of demand for floor area is given by $\Sigma \beta_{1 i} /\left(1-\Sigma \lambda_{i}\right)$, while the long-run price elasticity of demand for unit consumption is given by $\Sigma \beta_{2 i} /\left(1-\Sigma \Phi_{i}\right)$. For the purposes of the present work, the number of autoregressive and distributed lags are chosen ( $P, Q$ over summation symbols in Equations (2) and (3) respectively) so as to eliminate serial correlation of errors $\left(e_{t}\right)$.

\footnotetext{
${ }^{2}$ Alternatively HDD could be left out of the regression and the space heating component of the dependent variable normalized for average climate conditions. Tests with this option however produced ambiguous results perhaps because price elasticities are better calculated when they are related to the actual climate dependent demand that occurred.
} 
Figure 1 shows the time series of Unit Consumption $\left(I_{t}\right)$, heating degree days $\left(H D D_{t}\right)$ and energy prices $\left(P_{t}\right)$ and suggests that $H D D_{t}$ is stationary (its trajectory appears to be mean reverting), that Unit Consumption may be trend stationary but that energy prices is not stationary. In general stationary time series would not be included in a cointegration vector as they would not have a long run relationship with any non-stationary variables [17]. The HDD has however exerted a historic influence on unit consumption, as is evident in Figure 1 (e.g. Sweden from 1985 to 1987), and can be expected to do so for many decades into the future. The downward trajectory of Unit Consumption, also visible in Figure 1, suggests that it contains a long-term trend (which can be modelled as a time trend $(t)$ ) that can also be expected to continue into the future. Thus, the present paper suggests that the stationary time series of $H D D$ and $t$ when combined with the time series of energy prices (which appears to be non-stationary from Figure 1), are cointegrated with Unit Consumption. This is the theoretical grounding for the cointegration vector $\left(1, \alpha_{1}, \beta_{2}, \beta_{3}\right)$ which is the basis of Equation (2). The corresponding cointegration vector for Equation (3) is $\left(1, \beta_{1}\right)$. No other possible cointegration relationships e.g. setting price as the dependant variable, have been explored as this paper seeks to model the parameters of Equation (1) only.

\section{FIGURE 1 GOES HERE}

The time series were tested for stationarity and cointegration using the Augmented Dickey Fuller (ADF) version of the unit root test [17]. The tests revealed that all the time series of $H D D$ were stationary, whereas the time series for the other data categories were not stationary, with the exceptions of income per capita for Sweden and the UK and unit consumption for the UK. However, the first differences of the time series were found to be sufficient for creating stationary time series in all cases for which the original time series were not stationary (see Appendix A). The cointegration test shown in Appendix A indicates that the vectors proposed for Equations (2) and (3) are cointegrated, i.e., a long-run relationship exists between their variables, indicating that the results obtained from either an ARDL or a two-step ECM [18] regression of these parameters should be valid. In the early modelling for this paper similar results were obtained from an ARDL and a two-step ECM model of the parameters of Equation (2). As it is of interest in this work to isolate the effects represented by the time trend ( $t$ in Equation (2)) the ARDL model was chosen over the ECM. 


\section{$2.3 \quad$ Data series used}

The time series data for France, Italy, the UK, and Sweden used in Equations (1) to (3) were obtained from the following sources: personal income [gross/net household disposable income - real] and consumer price indices [private final consumption expenditure - deflator] [19]; energy carrier prices from 1978 to 2005 [20]; space and water heating demand by energy carrier from 1980 to 2005 [16]; and space and water heating demand by energy carrier and energy carrier prices from 1970 to 1985 [21]. All the economic data used are in the national currencies normalised to Year 2005. As the price data are for individual energy carriers, they have been weighted by the share of each energy carrier in the overall demand balance to produce a weighted average price for energy. For France, Italy, and Sweden, the price data for some energy carriers for some of the years were missing. For Sweden, the gaps were filled using data from the Swedish Energy Agency [22]. For France and Italy, data on the growth rates of complementary fossil fuels were used to estimate the missing prices. The IEA provides historical prices for coal, electricity, gas and oil, but not for biomass or district heating (DH). Prices for biomass and DH in Italy and UK were not needed due to the lack of penetration of these two energy carriers in these countries. Prices for DH in France and Sweden were obtained from [23]. For Sweden, biomass prices were based on the data provided by $[24,25]$. As no prices for biomass were found for France, the options for that country were to include biomass in the energy demand time series but not in the weighted average energy price time series or to omit biomass from the energy demand time series; tests to discover the best-fit model led to the latter option being chosen. For a review of the data availability for this type of work for any European country, see [26].

Ideally, the coefficients of Equation (2), should be calculated using time-series data dating back to at least 1970, so as to incorporate the price spikes of the 1970's while it may be advisable to use data from 1980 onwards to calculate the coefficients of Equation (3) as the high rate of construction in Europe during the 1970's may exaggerate subsequent estimations of these coefficients. The input data for Equation (2) for Italy and Sweden are available from 1970 to 2005, those for France are available from 1975 to 2005, and those for the UK are available from 1973 to 2005. For Equation (3) the input data used are from 1980 to 2005 except for Sweden for which they are from 1980 to 1992, as the floor area data post-1992 for that country are inconsistent ${ }^{3}$. Although [13] have shown higher price and income elasticities

\footnotetext{
${ }^{3}$ The issue related to the time series of floor area data for Sweden is discussed in [27].
} 
for the period 1970 to 1982 when energy prices were rising than the period 1982 to 1993 when they were quite static, in this work the elasticities are calculated for the periods outlined. The justification for this is that it allows for a long term analysis of demand drivers and long-term estimations of future demand. This assumption in developed further in the discussion.

\subsection{Scenario Description}

In the present study, a scenario is a set of assumptions made regarding future levels of exogenous parameters, such as population, average household size, personal income, and energy prices. Future estimations of population are available from various sources, e.g., [28]. These have been used to estimate the future numbers of households ( $A$ in Equation (1)) by dividing the population by the average household size in 2005. Average household size for 2005 was obtained by dividing the population in 2005 by the number of permanently occupied dwellings in each country, as obtained from [16] and shown in Table 1.

\section{TABLE 1 GOES HERE}

The recently published EU Roadmap for moving to a low-carbon economy in 2050 [29] estimates that the average household size for the EU-27 Countries will have fallen to 2.0 by 2050. In this work however the average household size is kept constant from 2006 to 2050 . In doing so it is assumed that if the number of people per household decreases, that there would also be a slower growth in floor area per household. As persons per household is not included in the model of floor area (Equation 3) it is assumed that the effects of smaller household and smaller floor area growth would cancel each other out, making a constant household size for the purposes of modelling energy demand seem reasonable.

The population projections used are from the EUROPOP2008 convergence scenario [30,31]. The population of the EU-27 is expected to grow by $0.2 \%$ per year until 2035 and slightly decline afterwards, remaining fairly stable at around 500 million over the next 40 years. The key drivers for demographic change are higher life expectancy, low fertility, and inward migration [29-31]. As the future population scenarios from Eurostat are only available for every $10^{\text {th }}$ year, the values have been interpolated to obtain a continuous population time series. 
Future estimations of income in the period from 2006 to 2050 are needed to calculate the future floor area, $S$, in Equation (3). For this purpose, growth of future income is set at 1.93\% per annum [32], without any adjustment for the post 2008 economic recession. This growth rate is taken from the Primes model which has been used to project EU energy demand to 2030 and provide a baseline and reference point for EU energy policy.

Future estimations of energy price levels in the period from 2006 to 2050 are also needed to calculate the unit consumption, $I$, in Equation2 (2). Three simplified price scenarios are used: 1) prices remain the same; 2) prices increase by $2 \%$ per year; and 3 ) prices increase by $3 \%$ per year for the weighted average price of energy from 2010 onwards. There are a number of reasons for this approach which are outlined as follows:

- These three price scenarios nearly cover the range of average annual percentage change in weighted energy price per country for space and water heating between 1970 and 2005 (France: 1.96\%, Italy: 3.04\%, Sweden: 3.22\%, UK: 0.59\%) ;

- The three price scenarios are similar to those used in the POLES global model for the EU Roadmap [29]. In that study, the three price scenarios used include one in which oil prices remain relatively stable at $70 \$ 2008 /$ barrel, one in which oil prices gradually double to $127 \$ 2008 /$ barrel by 2050 , and one in which temporary oil shocks from 2030 onwards lead to oil prices reaching $212 \$ 2008 /$ barrel by 2050 . In percentage terms, these represent annual increases of $0 \%, 1.5 \%$, and $2.75 \%$, respectively.

- The three price scenarios are also similar to the scenarios for future commodity prices for coal, oil, and gas, as estimated by the IEA in their World Energy Outlooks for 2009 and $2010[33,34]$;

- The three price scenarios are also similar to those obtained in an exercise for a previous work that involved an extensive estimation of future prices [35]. This exercise consisted of three steps - (i) estimation of future wholesale prices for energy using the price model ENPAC [36], (ii) estimation of future energy prices as seen by households by the addition to wholesale prices of estimations of future levels of distribution charges, VAT, excise taxes and carbon taxes and (iii) the use of future scenarios for the energy carrier mix as weights to make a future weighted average price for energy.

To summarise the four above points, despite the simplicity of the three price scenarios used, their values cover a range of prices obtained using more sophisticated methods. For a discussion on the possibility of future energy prices being higher than those used in these scenarios see the discussion section below. Prices for 2006 to 2009 are an interpolation between measured prices for 2005 and modelled prices for 2010 [35]. All future scenarios of unit consumption involving regressions that include lags use climate-corrected measured data for 2005 as their initial lagged inputs. For future scenarios of unit consumption, the 
coefficients of $H D D$ are suppressed, since their roles are to establish realistic price elasticities rather than to influence future consumption patterns.

\section{$3 \quad$ RESULTS}

This section lists the Index Decomposition (ID) results for each country, followed by the results of the OLS regressions of floor area per household and unit consumption using the ARDL. Then scenarios for energy demand to from 2006 to 2050 are presented. Note that as stated in Section 2 the number of households is not modelled using econometrics, as estimates of future population are obtained from other sources.

\subsection{Index Decomposition}

Figure 2 shows the Period-wise Index Decomposition profiles of the total energy demand for space and water heating for France, Italy, Sweden, and the UK in the period from 1970 to 2005. For all four countries, the increases in the number of households over the period, attributable to both rising population and smaller household sizes, and the larger average floor area per household due to increasing affluence, have increased the overall energy demand. This effect is strongest for Italy and UK. Improvements in efficiency have exerted an offsetting effect on this increased energy demand, mostly for France and Sweden. Sweden is the only one of the four countries in which total energy demand has decreased over the period. A key consideration in the following econometric sections is the linkage between the dynamics shown in Figure 2 and the various macroeconomic parameters.

\section{FIGURE 2 GOES HERE}

\subsection{Floor Area per Household}

Table 2 presents the results for a model of floor area per household, based on Equation (3). Each regression has a high Adjusted $\mathrm{R}^{2}$ and F-test statistic, with the exception of the F-test statistic for Sweden. The short-term income elasticities of demand were found to be low, ranging from 0.09 for Sweden and Italy to 0.02 for the UK, with negligible values for France. On the other hand, the lags of floor area per household, showed high coefficients for all four countries, and seemed to reduce the short-run income effect, thereby slowing the annual increase in floor area. This is reflected in the long-run income elasticities calculated. The low degrees of freedom in the models applied to Sweden did not seem to produce results that were in any way inferior to those from the other countries, although its F-test statistical value was the lowest. As no other income elasticities of demand for floor area per household have been 
found in the literature, comparisons with other studies are not possible. However, considering the results shown in Figure 2, the calculated long-term income elasticities suggest that increasing floor areas will continue to have a significant impact on total energy demand in Italy, Sweden, and the UK.

\section{TABLE 2 GOES HERE}

\subsection{Unit Consumption}

Table 3 presents the results for a model of unit consumption, based on Equation (2). The Adjusted $\mathrm{R}^{2}$ and F-test statistical values obtained are high. The short-term price elasticities of demand ranged from -0.06 for France to -0.21 for the UK. These elasticities are low but are not dissimilar to the results obtained in other studies $[5,13,37]$. The variability of these results, with lower elasticities observed for France, Italy, and Sweden compared with the UK, may be due to the former three countries having larger home rental sectors in which tenants have fixed costs for heating. Furthermore, Figure 1 shows that prices have fallen in France between the mid-1980s and 2004, which would also result in a very low price elasticity. The large share of electricity use in this country for space and water heating may also have had an impact. Coefficients for the time trend were found to be of the same order of magnitude for each country, although they ranged from $-0.001(-0.1 \%)$ in Italy to $-0.007(-0.7 \%)$ in the UK, suggesting that the effects of technical change and regulations have not been as pronounced in Italy. An brief examination of the new IEA BEEB (Building Energy Efficiency Policies) database [38] suggests that this can be the case. According to the information in the database the first building energy regulations were introduced in Italy in 2006 as compared to 1955, 1946 and 1976 for France, Italy and the UK respectively. The coefficients of $H D D$ are of similar order of magnitude and are highest for the UK and surprisingly lowest for Sweden, which has the coldest climate, i.e., the impact on unit consumption of the colder winters between 1970 and 2005 has been least potent in Sweden. This may be due to the higher levels of insulation in houses in Sweden ${ }^{4}$. The coefficients of the lag are similar for France, Italy, and Sweden, while they are negligible for the UK. The long-term price elasticities, which range from -0.17 for France to -0.35 for Italy, show that in the long run Italy and Sweden "catch up with and overtake" the UK in terms of response to price changes, whereas in France

\footnotetext{
${ }^{4}$ Werner (2006) suggests that the difference in unit consumption between say Sweden and UK is related by the square root of the number of heating degree days rather than the actual number of heating degree days, due to the higher insulation standards in Sweden.
} 
the effect is less pronounced, presumably reflecting its large share of electricity use for space and water heating.

Rebound effects, such as improved energy efficiency leading to increased indoor temperatures (see for example $[39,40]$ ) are not examined in the study due to a lack of reliable data on the development of indoor temperatures. However the dependent variable unit consumption $\left(\mathrm{kWh} / \mathrm{m}^{2} /\right.$ year) contains the aggregated development of indoor temperature, the annual duration of heating demand, and the technical efficiency of the buildings. Hence, it is possible that low elasticities between for example demand and energy price, are partly due to rebound effects.

The multicollinearity of the explanatory variables presented in Table 3 was checked by calculating the variance inflation factor (VIF) for each (see Appendix A). Results show the presence of multicollinearity for the trend and lag parameters for France and Italy. The coefficients of these parameters are thus highlighted in bold in Table 3. Although it is assumed that the presence of multicollinearity does not negatively affect the ability of the model to be used for forecasts [41] the individual coefficients (trend and lag) may be biased. As the lag is involved this has implications for the bias on the long term price elasticity calculated for these two countries as well.

\section{TABLE 3 GOES HERE}

Short-term price elasticities of -0.11 for Sweden and the UK have been reported by [13] but the same study showed insignificant results for France and Italy. This result for Sweden is similar to that obtained in the present work, whereas the value obtained previously for the UK is lower than that obtained for the UK in the present work. However it was also found [13] that the short-term and long-term elasticities for the UK were almost equal, which is similar to the finding of the present work. The discrepancies between the previous and present studies may be attributed to the time series used by [13] being shorter (1970-1993) and the fact that they studied the elasticities of all end-uses, i.e., not just space and water heating.

As described in Sections 2.1 and 2.2, income was not included as an independent variable for unit consumption, but only to explain the development of floor area. This means that the risk of multicolinearity between income and the time trend is avoided. Nonetheless, tests to include income gave results that were difficult to interpret or to relate to any theoretical 
understanding: for Sweden and the UK, income was not significant in the regression analysis and its inclusion had almost no impact on the other coefficients; for France, the income elasticity was positive and for Italy, it was negative. In both of these countries, the inclusion of income also reduced the price elasticity and its level of significance. The inclusion of income reduced the F-test statistical values of the regressions for all the countries, with the exception of France, where it resulted in a slight increase.

\subsection{Scenarios}

Figure 3 shows the outcomes of modelling floor area per household from 2006 to 2050 using the coefficients described in Table 2 and an income per capita growth rate of $1.93 \%$ per annum. The figure also shows measured data from 1980 to 2005 . The modelling reveals an increase in floor area demand in each country. This is consistent with the results obtained for the EU as a whole in the EU Roadmap report [29], although the methodology used in that report was not given. Figure 3 shows a slow growth in floor area demand for France. This is expected given the negligible income elasticity of demand calculated for this country (Table 2 ). For the other countries, the increase in floor area demand was $0.37 \%$ per year for Sweden and $0.42 \%$ per year for Italy and the UK. It is clear that for Sweden and the UK the 2006 to 2050 scenario follows the trajectory of the historical data. For Italy, the results resume the long-term upward trend after a dip between 2006 and 2010. This dip corresponds to a dip in the measured data for 2004 to 2005 (only barely visible in Figure 3).

The aforementioned EU Roadmap [29] estimated the EU average floor area per household at $113 \mathrm{~m} 2$ for 2050 . This value is similar to those reported in the present work for Italy and Sweden $\left(115 \mathrm{~m}^{2}\right.$ and $119 \mathrm{~m}^{2}$, respectively), but higher than the values for France and the UK (91 $\mathrm{m}^{2}$ and $107 \mathrm{~m}^{2}$, respectively). Five studies for Germany have been cited by [42], each of which show floor area growing at $0.5 \%$ per annum between 2009/2010 and 2050, although again the methodology used in the studies was not given. If one assumes that the average annual income increase in Germany will be greater than the EU average used in the present study, then it makes sense that the annual growth in floor area reported in the present study is lower than that found for Germany. Regardless, the increase in floor area for all the countries listed in Figure 3 indicates that this parameter can be expected to have a continued upward effect on total energy demand.

\section{FIGURE 3 GOES HERE}


Figure 4 shows the corresponding modelling results for unit consumption from 2006 to 2050 obtained using the coefficients described in Table 3 and the three price scenarios. Figure 4 also includes measured data from 1970 to 2005 (1975 for France and 1972 for the UK). Depending on the price scenario chosen for the four countries, unit consumption decreases as follows: for France, from $150 \mathrm{kWh} / \mathrm{m}^{2}$ to between $90 \mathrm{kWh} / \mathrm{m}^{2}$ and $75 \mathrm{kWh} / \mathrm{m}^{2}$; for Italy, from $131 \mathrm{kWh} / \mathrm{m}^{2}$ to between $90 \mathrm{kWh} / \mathrm{m}^{2}$ and $75 \mathrm{kWh} / \mathrm{m}^{2}$; for Sweden, from $171 \mathrm{kWh} / \mathrm{m}^{2}$ to between $90 \mathrm{kWh} / \mathrm{m}^{2}$ and $65 \mathrm{kWh} / \mathrm{m}^{2}$; and for the UK, from $184 \mathrm{kWh} / \mathrm{m}^{2}$ to between 120 $\mathrm{kWh} / \mathrm{m}^{2}$ and $95 \mathrm{kWh} / \mathrm{m}^{2}$. In the high price scenario, these figures represent approximate average annual demand decreases of $1.5 \%$ for France and the UK, 1.2\% for Italy, and 2\% for Sweden or overall reductions in demand of $50 \%, 42 \%, 38 \%$, and $51 \%$, respectively. Although the price elasticities used in these scenarios are highest for Italy and lowest for France (see Table 3), the results obtained are also determined by the effects of trend, lags, and HDD, and suggest that on the whole there is a higher sensitivity to changes in these parameters in Sweden than in the other three countries.

\section{FIGURE 4 GOES HERE}

In a contribution to IIASA's Global Energy Assessment the retrofitting of the existing dwelling stock in Western Europe to achieve a unit consumption of between $15 \mathrm{kWh} / \mathrm{m}^{2}$ and $20 \mathrm{kWh} / \mathrm{m}^{2}$ by 2050 is advocated [43], so as to avoid what they termed the long-term lock-in effects of sub-optimal retrofits, meaning that if retrofitting does not occur prior to heating system replacement then the lost savings potential will be "locked" in place until the next building rennovation. Such a level of retrofitting would bring the building stock close to the passive house standard for space heating of $15 \mathrm{kWh} / \mathrm{m}^{2} /$ year as set by the German Passive House Institute [44]. Two studies where the contribution of buildings to significant $2050 \mathrm{CO}_{2}$ reduction goals do not require their reaching the passive standard are; [45] for Denmark, which described three technology-based scenarios in which the unit consumption for space heating and hot water of dwellings was between $20 \mathrm{kWh} / \mathrm{m}^{2}$ and $55 \mathrm{kWh} / \mathrm{m}^{2}$ depending on the dwelling types and; [46] for UK where unit consumption for space and water heating falls to $60 \mathrm{kWh} / \mathrm{m}^{2}$. Thus, it can be concluded that the level of unit consumption calculated in this work for 2050 is quite different from the passive house standard notwithstanding that a proportion comes from water heating. Hence, as expected the three annual price-change scenarios are far from sufficient to reduce unit consumption to passive house standard. 
The annual price increases that would be necessary with the coefficients in Table 3 to reduce unit consumption for space and water heating below $30 \mathrm{kWh} / \mathrm{m}^{2}$ are $20 \% 11 \%, 11 \%$, and $18 \%$ for the four countries respectively. Given that the $3 \%$ annual increase in energy prices is historically high for a period of 45 years, additional policy measures and regulations are obviously required to achieve such targets. On the other hand the value for energy use for space and water heating of $65 \mathrm{kWh} / \mathrm{m}^{2}$ for Sweden in 2050 obtained in this work may represent a sustainable solution from the emissions and systems perspectives, if a carbonneutral district heating still exists in that country. This is uncertain given the fact that more efficient dwellings and less waste incineration may make the DH system there unviable. The Heat Roadmap Europe project [47] however which looks at prospects for district heating in the EU to 2050, finds that to meet an ambitious $\mathrm{CO}_{2}$ reduction goal that $\mathrm{DH}$ is a cheaper option than deep energy efficient renovation. The study gives ample evidence to suggest that there could be more and not less carbon-neutral district heating systems across the EU in 2050.

In the transition between the measured data (pre-2005) and estimated scenarios (post-2005) shown in Figure 4, some interesting effects are noted for Italy and the UK. For Italy in the period 2003-2005, prices decreased but the weather was colder compared to the previous two years, leading to a large increase in the use of natural gas for both space and water heating. This led to an overall rise in unit consumption (see also Figure 1). This of course influenced developments in the first years of the post-2005 scenario, although by 2008 the parameter had returned to the long-term downward trend that has been in place since the 1970's. For the UK, there was a large nominal increase in prices for energy carriers between 2004 and 2005, and although these increases were not that large when adjusted for inflation, they still caused a dip in demand for space heating energy. The weather in the period from 2003 to 2005 was milder than that in the period from 2000 to 2002, which would have helped householders to lower energy use for heating without experiencing significant discomfort. Then. as the lag of demand used for the 2006 price scenario is climate corrected and thus higher than measured demand for 2005, this causes the apparent spike in unit consumption observed for 2006 in Figure 4. Between 2006 and 2011 when the trajectory of unit consumption changes again, the modeled price increase is greater than $3 \%$ so that after 2011 the price effect is reduced causing an upward swing in the trajectory of unit consumption in each scenario. 
Returning to Equation (1), the results for floor area and unit consumption were combined with an estimation of the number of households per country (See Section 2.4), to produce three scenarios for total energy demand for space and water heating from 2006 to 2050 . The results (presented in Figure 5) estimate that overall energy demand falls for all the countries and for all the scenarios, except in the case of the $0 \%$ price change scenario for Italy. For France, a $3 \%$ annual price increase results in a $1 \%$ decrease in average annual demand. For Italy, the corresponding value is $0.7 \%$ and for Sweden, it is $1.3 \%$, while for the UK, it is $0.6 \%$. These figures represent overall demand decreases of $39 \%, 27 \%, 45 \%$, and $22 \%$, respectively, which reflect the combined influence of numbers of households, increases in floor area per household, and reductions in unit consumption. For example, for the UK, the influences of increasing floor area and the number of households offset the fall in unit consumption, thereby creating a change in the trajectories of the three scenarios from 2011 onwards. For France, the fact that floor area hardly changes between 2006 and 2050 gives a reduction in overall energy demand, despite it being fairly constant from the 1970 's to 2005 .

\section{FIGURE 5 GOES HERE}

The 2\% scenario results presented in Figure 5 are decomposed in Figure 6, to visualise the temporal partial influences that $A, S$, and $I$ would have on energy demand for space and water heating over the period 2005-2050. Compared to the corresponding index decomposition for the historical data (1975-2005), as given in Figure 2, Figure 6 shows diminished roles for floor area trends for France and for the numbers of households for Italy and Sweden. For the UK, there are slight decreases in the effects of numbers of households and floor area per household compared to the historical data. For France and the UK, decreased unit consumption over the period becomes the dominant parameter affecting total demand, This effect is not as strong for Italy. For Sweden, unit consumption has a slightly diminished role. Examining Figure 6, the continuing household number and floor area dynamics in the UK and the slower decrease in unit consumption in Italy suggest that overall energy demand will not decrease as much in these two countries as it will in France and Sweden.

\section{FIGURE 6 GOES HERE}

It is not possible to relate the results in Figure 5 to those from the EU Roadmap [29], as that publication focuses on carbon emissions and useful energy demand, which are not the focuses 
of the present paper. Neither is it possible to relate Figure 5 to the EU indicative 20\% savings from efficiency by 2020 target as it is specified in primary energy. Relating the present results to those obtained from the Primes 2007 Model [32] or the Renewable Energy Action Plans of individual countries (REAP) [48] is also problematic, as these two publications do not specifically describe space and water heating in the residential sector. In the absence of a political goal to relate the results to, the results presented in Figure 5 are compared to an arbitrary goal of a compounded 1\% saving in total demand per year between 2006 and 2050 . This arbitrary goal is indicated in Figure 5 by the squared marker in 2050. This goal is similar to that being used for the EU Energy Services Directive, wherein savings of $1 \%$ of the Final Energy Demand are expected to be made between 2009 and 2016 [49]. However, this target is lower than the national energy saving obligation schemes, which aim for annual final energy reductions of 1.5\%, as included in the new EU directive on Energy Efficiency [50] and thus not especially ambitious. The results presented in Figure 5 show that in the high-price scenario, that total energy demand in France and Sweden is on or close to the target value. This is not the case for Italy and the UK. These findings indicate that the price and other mechanisms described in Equation (2) are sufficient to meet such a target for France and Sweden, whereas other measures will be necessary for Italy and the UK.

\section{$4 \quad$ DISCUSSION}

While increasing energy prices have a significant impact on energy demand in the scenarios for all the countries, it is noteworthy that even the scenarios with zero increases in energy prices show considerable reductions in unit consumption. Comparing the scenarios of $0 \%$ and $3 \%$ increases in energy prices per annum as shown in Figure 4, the price increase accounts for 20\%-30\% of the reduction for France, Sweden and the UK and $70 \%$ for Italy only. Even after considering the increasing floor areas, this non-price effect is sufficiently strong to result in decreased total energy demand in France and Sweden (Figure 5).

The reason for this is the impact of the time trend coefficient, as included in the regressions for unit consumption (Equation 2 and Table 3). The question then arises as to how this result should be interpreted. The time trend coefficient captures gradual changes in unit consumption over time that cannot be attributed to changes in prices or climate (heating degree days). That a large part of the reduction in unit consumption is attributed to the time parameter does not mean that this reduction occurs "by itself” as time passes. Non-price 
policy measures have certainly affected the gradual energy efficiency improvements seen in the past and they are also indirectly incorporated into the time trends of the scenarios.

Examples of such policies include energy standards for new buildings, support for the development of new technologies, and subsidies for technology diffusion. It has been estimated that between 1975 and 2000, about one third of the energy efficiency improvements in the Swedish residential building stock were due to the addition of new, more energy efficient buildings [27]. In the absence of a strategy for continually strengthening the energy standards for new buildings or the support for energy efficient buildings, such as passive houses, the addition of new buildings may simply contribute to increasing floor areas rather than lowering the average unit consumption of the stock. The correct interpretation is then that in order to achieve the reductions in energy demand suggested by the time trend, nonprice policies will have to continue according to historical patterns. This means that the incrementally improving ambition of the non-price policies enacted between 1970 to 2005 must continue, going forward. If however future policy making in this sector will rely solely on the price mechanism, then the scenarios presented in Figure 4 and 5 will need to be corrected upwards

What is thus the price effect shown in this paper? Increasing energy prices from the low-price scenario to the high-price scenario offers a gain of around $25 \mathrm{kWh} / \mathrm{m}^{2}$, i.e., a further reduction in unit consumption. This is significant in itself, but, in the context of average unit consumption of over $130 \mathrm{kWh} / \mathrm{m}^{2}$ in 2005 , is not a large reduction for a 45 year period (See Figure 4 ). The long run price elasticity is low (mean of -0.25 over the four countries) and it has been calculated in this paper that annual prices rises of over $10 \%$ would be necessary to reduce unit consumption below $30 \mathrm{kWh} / \mathrm{m}^{2} /$ year by 2050 . Over the period 1970 to 2005 , the only sustained time when price rises of over $3 \%$ per annum occurred was during the two major oil crises of the 1970 's ${ }^{5}$. Although such oil price spikes could undoubtedly occur again the residential sector heating should be less exposed because the fuel mix for heating has diversified since the 1970's to include more natural gas, biomass, electricity and district heating [16] and global reserves of natural gas are increasing at the same time as its price is decoupling from that of oil $[51,52]$. In addition the possibility of increased incidence of fuel

\footnotetext{
${ }^{5}$ The annual percentage price change between 1970 and 2005 is highly influenced by the average annual price change between 1970 to 1982 (France: 10.73\%, Italy: 9.18\%, Sweden: 8.17, UK: 3.25\%) while the average annual price change is negative for three of the countries between 1983 to 2005 (France: -0.93\%, Italy: -0.17\%, Sweden: 0.62, UK: $-0.78 \%$ )
} 
poverty with rising energy prices [53] is one reason that legislated price increases e.g. carbon taxes, are politically difficult to impose to any extent that can be equated with significant long-term increases in prices. On the other hand the predominance of natural gas heating in the sector (nearly half of the fuel used for heating in the four countries combined) means that there is exposure to rising prices of this commodity that could be brought about by for example geo-political conflicts or less than expected supplies from unconventional sources. However as a $3 \%$ annual price increase over 45 years amounts to a $378 \%$ increase for the period it is assumed that any such price increases are below this level. The implication of this is that the policy effect of rising prices in the residential sector is significant but not sufficient and that to meet relevant EU goals more non-prices policy measures are necessary.

The EU Roadmap (2011a) [29] states that as long as sufficiently stringent carbon price incentives across sectors can be put in place, the emission reductions of $80 \%$ to be accomplished by 2050 will be enabled mostly by changes in technology plus "a modest contribution" from price-induced changes in behaviour. With regard to (direct) emissions from the residential sector the specific goal of the EU Roadmap in 2050 is a reduction by $90 \%$ although the key enabling measures proposed for this sector are new financing models. Thus price-induced changes in technology are not considered to be paramount in the residential sector. To meet the goal outlined in the EU Roadmap for the residential sector then, the price effects shown in the present paper would have to be combined with financial instruments that lead to changes in technology e.g. the deployment of more carbon-neutral heating systems and retrofitting. This would be equivalent of increasing the effect of non-price policy measures (represented in the model by the time trend). In a similar work examining the energy efficiency gap for space heating the authors of this paper show that the annual rate of technical development, legislation and regulations applied would need to be doubled to realise the techno-economic savings potential for the case of the Swedish Residential Sector by 2030 [35]. In a bottom-up study the authors also show that a combination of minimum efficiency construction standards, improved conversion efficiency standards for final energy to useful energy, and $\mathrm{a} \geq 2 \%$ annual improvement in end-use efficiency applied at the useful energy level can halve EU primary energy demand in the building sector to 2050 [54]. This gives an indication of the need for an increase in non-prices policy measures that are necessary to meet EU goals. 
Results shown in Figure 4 indicate that the average unit consumption for each country is a long way from the passive standard by 2050. Although the EU Roadmap [29] describes decarbonisation scenarios where there is gradual replacement of the housing stock with passive housing after 2040, with an annual stock replacement rate (ratio of annual demolition to the size of existing stock) of only $0.07 \%$ [55], it would take more than 1000 years for the housing stock to be replaced by new houses of passive standard. Rather than replacing the existing residential building stock with Passive houses, a retrofitting the existing residential building stock to the passive standard at a rate of $1.3 \%$ per annum to 2019 , increasing through learning and up-skilling to 3\% per annum in the period from 2020 to 2050 , has been suggested [43]. The results obtained in the present work show that such an effort would require far more than price mechanisms to succeed and reemphasise the limits of the price effect. To be more prescriptive than this in terms of non-price policy proposals would however require analysis using a detailed bottom-up model. The requirement that after 2020 that all new dwellings constructed in the EU are net zero energy buildings [50] is obviously a step in this direction. This impact of this development on results is something that could be explored in a further development of this paper.

\section{$5 \quad$ CONCLUSION}

The present work employs the index decomposition approach pioneered by Ang [11] and Schipper [12], the cointegration analysis approach described by Bentzen and Engsted [8], and the scenario modelling approach described by Chateau and Lapillonne [10] to show the temporal partial influences of various broad technical and non-technical factors that influence energy demand for space and water heating such as energy prices, energy efficiency and floor area per household. The emphasis of the work is the aggregated energy demand for space and water heating and not the specific energy carriers. Hence energy prices have also been measured as weighted average prices. The implication of energy carrier mix on aggregated demand could be further explored in further research.

The results obtained for the four EU countries examined in the work (France, Italy, Sweden and the UK) show that although greater affluence and larger floor areas increase energy demand ceteris paribus, higher energy prices can offset this increase for space and water heating. In a scenario where energy prices do not change, unit consumption ( $\mathrm{kWh} / \mathrm{m}^{2} /$ year) falls in each of the four countries (Figure 4). However, this does not imply that energy demand would decrease by itself. Rather, the implementation of non-price policies such as 
energy efficiency standards and support for new technologies will have to continue along the historical rate of ambition. In a scenario with energy price increases of 3\% per year, energy demand is projected to fall by approximately $1 \%$ per year (Figure 5). About half of this reduction can be attributed to the price elasticity and the remainder to the historical rate of non-price induced technical progress, for example through building codes and other policy instruments. As price increases of $>3 \%$ per annum are unlikely, price rises will need to be combined with increased implementation of non-price policies to reduce final energy demand in the residential sector of the EU at levels greater than $1 \%$ per year.

\section{ACKNOWLEDGEMENTS}

This work is co-funded by the projects "Pathways to a Sustainable European Energy System" and "Pathways to a Sustainable European Energy System - svenska systemlösningar" (Swedish Energy Agency). The author thanks Vincent Collins, Carsten Hansen, Roger Wahlberg and Guo $\mathrm{Xu}$, for tips and suggestions related to the work. 
[1] EC. Action plan for energy efficiency: realising the potential. COM(2006)545. European Commission; 2006.

[2] EC. Energy efficiency: delivering the 20\% target. COM(2008)772. European Commission; 2008.

[3] Dahl CA. A Survey of Energy Demand Elasticities in Support of the Development of the NEMS. Colorado School of Mines; 1993.

[4] Madlener R. Econometric Analysis of Residential Energy Demand: A Survey. J Energy Lit II 1996:3-32.

[5] Athukorala PPAW, Wilson C. Estimating short and long-term residential demand for electricity: New evidence from Sri Lanka. Energy Econ 2010;32, Supplement 1:S34-40. doi:10.1016/j.eneco.2009.08.005.

[6] Bentzen J, Engsted T. Short- and long-run elasticities in energy demand: A cointegration approach. Energy Econ 1993;15:9-16. doi:10.1016/0140-9883(93)90037-R.

[7] Pesaran MH, Shin Y. An autoregressive distributed lag modelling approach to cointegration analysis. In: Strøm S, editor. Econometrics and economic theory in the twentieth century: the Ragnar Frisch Centennial Symposium. Cambridge: Cambridge University Press, 1999.

[8] Bentzen J, Engsted T. A revival of the autoregressive distributed lag model in estimating energy demand relationships. Energy 2001;26:45-55. doi:10.1016/S0360-5442(00)000529.

[9] Sterman JD. A skeptic's guide to computer models. Manag Nation Microcomput Softw Cat 1991;2:209-29.

[10] Chateau B, Lapillonne B. Long-term energy demand forecasting A new approach. Energy Policy 1978;6:140-57. doi:10.1016/0301-4215(78)90035-6.

[11] Ang BW, Zhang FQ. A survey of index decomposition analysis in energy and environmental studies. Energy 2000;25:1149-76. doi:10.1016/S0360-5442(00)00039-6.

[12] IEA. Indicators of Energy Use and Efficiency - Understanding the link between energy and human activity. Paris: IEA; 1997.

[13] Haas R, Schipper L. Residential energy demand in OECD-countries and the role of irreversible efficiency improvements. Energy Economics 1998;20:421-42. doi:10.1016/S0140-9883(98)00003-6.

[14] Nässén J, Sprei F, Holmberg J. Stagnating energy efficiency in the Swedish building sector-Economic and organisational explanations. Energy Policy 2008;36:3814-22. doi:10.1016/j.enpol.2008.07.018.

[15] Filippini M, Hunt LC, Zorić J. Impact of energy policy instruments on the estimated level of underlying energy efficiency in the EU residential sector. Energy Policy 2014;69:73-81. doi:10.1016/j.enpol.2014.01.047.

[16] Enerdata. Odyssee Database. 2013. Available from: http://www.odysseeindicators.org.

[17] Enders W. Applied Econometric Time Series, 2nd Edition. Hoboken, NJ: Wiley; 2003.

[18] Engle RF, Granger CWJ. Co-integration and Error Correction: Representation, Estimation, and Testing. Econometrica 1987;55:251-76.

[19] OECD. Economic Outlook No 84: Annual and Quarterly data. Paris: OECD; 2008.

[20] IEA. IEA Energy Prices and Taxes Statistics, OECD iLibrary 2012. doi:10.1787/eneprice-data-en.

[21] Schipper L. Personal communication with author 2010. 
[22] Energimyndigheten. Ny publikation: Energiläget 2007. Swedish Energy Agency;.2007 [in Swedish].

[23] Werner S. Personal communication with author 2009.

[24] Björheden R. Drivers behind the development of forest energy in Sweden.

Biomass Bioenergy 2006;30:289-95. doi:10.1016/j.biombioe.2005.07.005.

[25] Junginger M, Faaij A, Björheden R, Turkenburg WC. Technological learning and cost reductions in wood fuel supply chains in Sweden. Biomass Bioenergy 2005;29:399-418. doi:10.1016/j.biombioe.2005.06.006.

[26] Ó Broin E. Energy Demands of European Buildings: A Mapping of Available Data, Indicators and Models. Master Thesis, Chalmers University of Technology Report No. T2007-307, 2007. Available from:

http://publications.lib.chalmers.se/publication/136409

[27] Nässén J, Holmberg J. Energy efficiency - a forgotten goal in the Swedish building sector? Energy Policy 2005;33:1037-51. doi:10.1016/j.enpol.2003.11.004.

[28] Eurostat. Eurostat Population Projections to 2060. Downloaded on 11 Mar 2009 10:19:21 GMT. Document had been last updated on 09.01.2009.

http://epp.eurostat.ec.europa.eu/tgm/table.do?tab=table\&init=1\&plugin=1\&language $=$ en $\&$ pcode $=$ tps00002. Current projections available from:

http://epp.eurostat.ec.europa.eu/portal/page/portal/population/data/database

[29] EC. A Roadmap for moving to a competitive low carbon economy in 2050. COM(2011)112. European Commission; 2011.

[30] Eurostat. Population projections article in statistics explained section of website, 2011. URL:

http://epp.eurostat.ec.europa.eu/statistics_explained/index.php/Population_projections

[31] Eurostat. Regional population projections EUROPOP2008: Most EU regions face older population profile in 2030; 2010. URL:

http://epp.eurostat.ec.europa.eu/cache/ITY_OFFPUB/KS-SF-10-001/EN/KS-SF-10-001EN.PDF

[32] EC. European energy and transport trends to 2030dupdate 2007. European Commission Directorate-General for Energy and Transport. European Communities, ISBN 978-92-79-07620-6; 2008.

[33] IEA. World Energy Outlook 2009. Paris, France: OECD/IEA, 2009: ISBN: 978-92-64-06130-9

[34] IEA. World Energy Outlook 2010. Paris, France: OECD/IEA, 2010: ISBN: 978-926408624 1

[35] Ó Broin E, Mata É, Nässén J, Johnsson F. Quantification of the Energy Efficiency Gap in the Swedish Residential Sector. Submitt Publ 2013.

[36] Harvey S, Axelsson E. Scenarios for assessing profitability and carbon balances of energy investments in industry. Chalmers University of Technology; 2010: ISBN: 97891-978585-0-2.- 42

[37] Nässén J, Sprei F, Holmberg J. Stagnating energy efficiency in the Swedish building sector-Economic and organisational explanations. Energy Policy 10;36:381422. doi:10.1016/j.enpol.2008.07.018.

[38] IEA. Buildings Energy Efficiency Policy Database - Sustainable Buildings Center 2014. Available from: http://www.sustainablebuildingscentre.org/pages/beep.

[39] Milne G, Boardman B. Making cold homes warmer: the effect of energy efficiency improvements in low-income homes A report to the Energy Action Grants Agency Charitable Trust. Energy Policy 2000;28:411-24. doi:10.1016/S03014215(00)00019-7. 
[40] Nässén J, Holmberg J. Quantifying the rebound effects of energy efficiency improvements and energy conserving behaviour in Sweden. Energy Effic 2009;2:221-31. doi:10.1007/s12053-009-9046-x.

[41] Gujarati D, Porter D. Essentials of Econometrics. 5th edition. Boston, Mass., USA: Mcgraw-Hill College; 2015.

[42] Lechtenböhmer S, Samedi S, Schneider C. The potential role of energy efficiency in the transition to a low carbon society - a critical scenario review. ECEEE Energy Effic. First Conf. Proc., 2011. Available from: http://www.eceee.org/library/conference_proceedings/eceee_Summer_Studies

[43] Ürge-Vorsatz D, Petrichenko K, Butcher AC. How far can buildings take us in solving climate change? A novel approach to building energy and related emission forecasting. ECEEE Energy Effic. First Conf. Proc., 2011. Available from: http://www.eceee.org/library/conference_proceedings/eceee_Summer_Studies

Feist W. Certification as" Quality Approved Passive House" Criteria for Residential-Use Passive Houses. Passive Haus Inst, Darmstadt, Germany 2007.

[45] Wittchen K, Kragh J, Jensen OM. Energy-saving potential - a case study of the Danish building stock. ECEEE Energy Effic. First Conf. Proc., 2011. Available from: http://www.eceee.org/library/conference_proceedings/eceee_Summer_Studies

[46] Eyre N. Efficiency, Demand Reduction or Electrification? ECEEE Energy Effic. First Conf. Proc., 2011. Available from: http://www.eceee.org/library/conference proceedings/eceee Summer_Studies

[47] Connolly D, Lund H, Mathiesen BV, Werner S, Möller B, Persson U, et al. Heat Roadmap Europe: Combining district heating with heat savings to decarbonise the EU energy system. Energy Policy 2014;65:475-89. doi:10.1016/j.enpol.2013.10.035.

[48] EC. National Renewable Energy Action Plans 2010. Available from: http://ec.europa.eu/energy/renewables/action_plan_en.htm.

[49] EC. Directive 2006/32/EC of the European Parliament and of the Council of 5 April 2006 on energy end-use efficiency and energy services and repealing Council Directive 93/76/EEC. European Commission; 2006.

[50] EC. Directive 2012/27/EU of the European Parliament and of the Council of 25 October 2012 on energy efficiency, amending directives 2009/125/EC and 2010/30/EC and repealing directives 2004/8/EC and 2006/32/EC. European Commission; 2012.

[51] Kjärstad J, Odenberger M, Johnsson F. Gas abundance and delayed CCS. Pathways Project report, Chalmers University of Technology. 2013.

[52] IEA. World Energy Outlook 2012. Paris, France: OECD/IEA, 2012: ISBN: 978-92-64-18084-0

[53] Liddell C. Fuel poverty comes of age: Commemorating 21 years of research and policy. Energy Policy 2012;49:2-5. doi:10.1016/j.enpol.2012.02.036.

[54] Ó Broin E, Mata É, Göransson A, Johnsson F. The effect of improved efficiency on energy savings in EU-27 buildings. Energy 2013;57:134-48. doi:10.1016/j.energy.2013.01.016.

[55] Enper Tebuc. Energy Performance of Buildings - Application of Energy Performance Regulations to Existing Buildings. Final report of Task B4, Enper Tebuc, SAVE II Programme 1998-2002; 2003. 


\section{APPENDIX A}

This appendix contains the results of tests of stationarity, cointegration, and multicolinearity.

\section{A.1 Tests of Stationarity}

Each of the individual time series used in Equations (2) and (3) was tested for stationarity by applying the ADF unit root test [17] (Enders, 2004).

\section{TABLE A.1 GOES HERE}

From the results listed in Table A.1 the following can be observed: whether the time series is stationary or not; the critical tau value for the test; and the number of augmentation lags needed to eliminate serial correlation. The $1 \%, 5 \%$, and $10 \%$ critical tau values for the unit root test are $-4.067,-3.46$, and -3.2447 , respectively [41]. The start years for the time series of Unit Consumption, Price and HDD are as indicated in Column 1, whereas the start year for Income and Floor Area is 1980. All the time series are to 2005, except for the floor area series for Sweden, which is to 1992.The time series for HDD are all stationary. The time series for the Unit Consumption, Price, Income and Floor Area are found to be non-stationary, I (1), with the exceptions of the income per capita for Sweden and the UK and unit consumption for the UK.

\section{TABLE A.2 GOES HERE}

Thus the same testing procedure was performed for the first differences of the time series shown in Table A.1 that were found to be non-stationary. The results of the tests given in Table A.2 show that the differencing process has been sufficient to create stationary time series, I (0), for the time series that were I(1) in their levels.

\section{A.2 Tests of Cointegration}

Table A.3 and Table A.5 present the results of the OLS regression in levels of Equations (2) and (3) the proposed cointegration vectors for the models of floor area per household and unit consumption. The number of lags (P,Q) are set to zero [17] (Enders, 2004). The input data for France, Italy, and the UK are from 1980 to 2005, while those for Sweden are from 1980 to 1992. Heteroscedasticity robust critical t statistical values are not presented due to the possibility that the regression is spurious. 


\section{TABLE A.3 TO A.6 GO HERE}

Tables A.4 and Table A.6 give the results of the unit root tests of the errors from Equations (2) and (3). The Lag $\Delta$ error (e) values are the augmentation lags needed to eliminate serial correlation. The critical t statistical values for these lags are shown in parentheses. The values in parentheses after the Lag error parameters in Tables A.4 and Table A.6 are the Engle and Granger tau values, which should be $>1.9$ (the 5\% level) in order to indicate cointegration (Gujarati, 2006). This is the case for all four countries with respect to both the floor area per household and unit consumption. This indicates that the vectors proposed in Equations (2) and (3) are cointegrated, i.e., a long-run relationship exists between their variables, suggesting that the results from the ARDL regressions of these parameters are valid.

\section{A.3 Tests of Multicolinearity}

Table A.7 shows the results of VIF tests on the explanatory variables proposed for modelling unit consumption in Equation (2). A VIF $\geq 10$ was taken to indicate the presence of multicolinearity. For France and Sweden, a collinear relationship was observed between both the lags, and the trend, while for Italy and UK no collinear relationships were found. A collinear relationship between lag and trend is expected, given that it is very similar to the relationship between demand and trend, with the lag corresponding to energy demand with a 1-year delay. As described in Section 2.2, the present work proposes a relationship between energy demand and trend that is expected to continue in the future, given the effects of longterm policies and technological developments. A similar long-term relationship between the lags and trend is therefore assumed to exist. However, since the relationship is expected to continue in the long run, such multicolinearity is assumed not to have a negative effect on any forecast [41]. On the other hand because of the bias that may be introduced by the effects of multicolinearity one cannot be sure that the coefficients of the lags and trend for France and Sweden are unbiased estimators.

\section{TABLE A.7 GOES HERE}




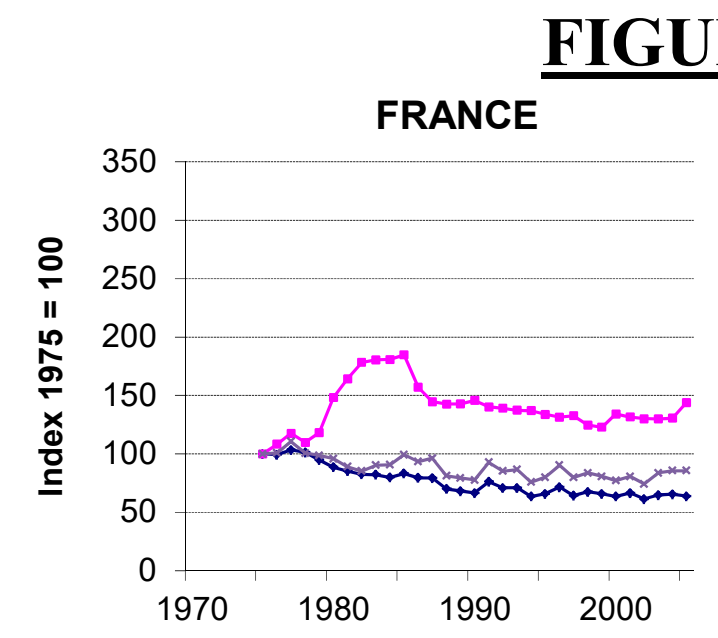

ITALY
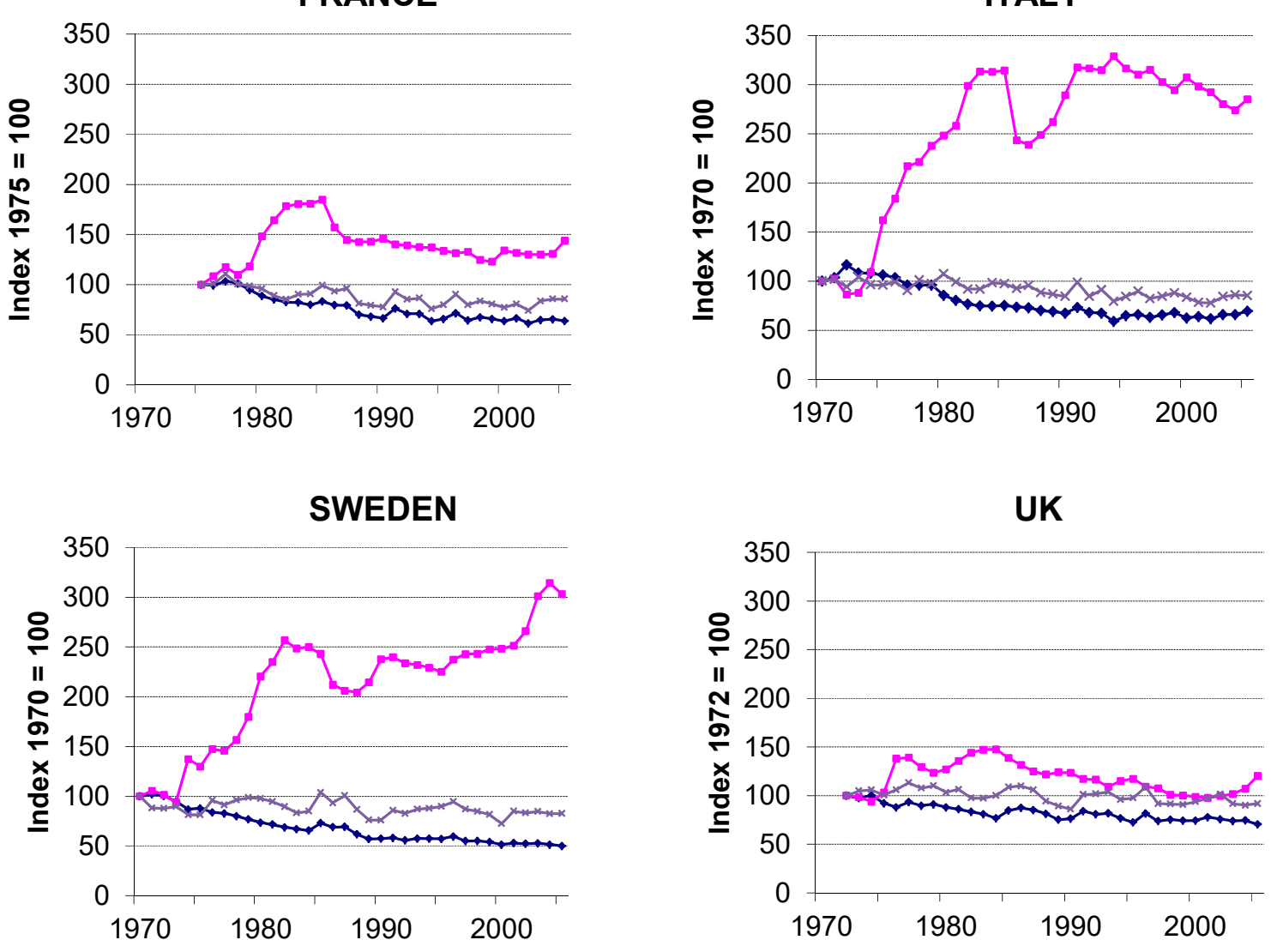

$\multimap$ Unit Consumption $\multimap$ Energy Price $\multimap$ HDD

Figure 1 : Indices of time series of Unit Consumption for Space and Water Heating $(\Lambda)$, energy prices $(P)$, and Heating Degree Days (HDD) for 1970 to 2005. 
FRANCE

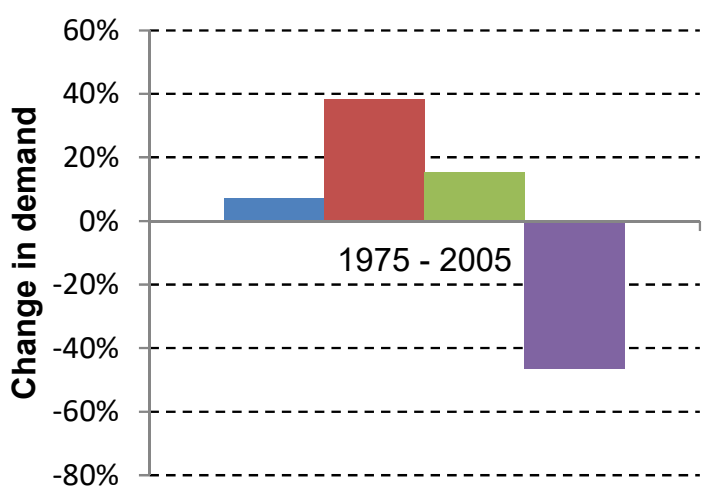

SWEDEN

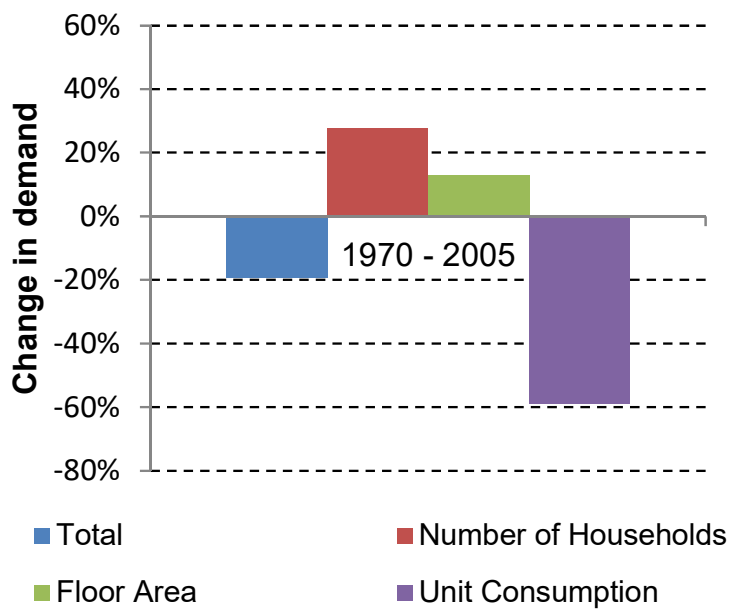

ITALY

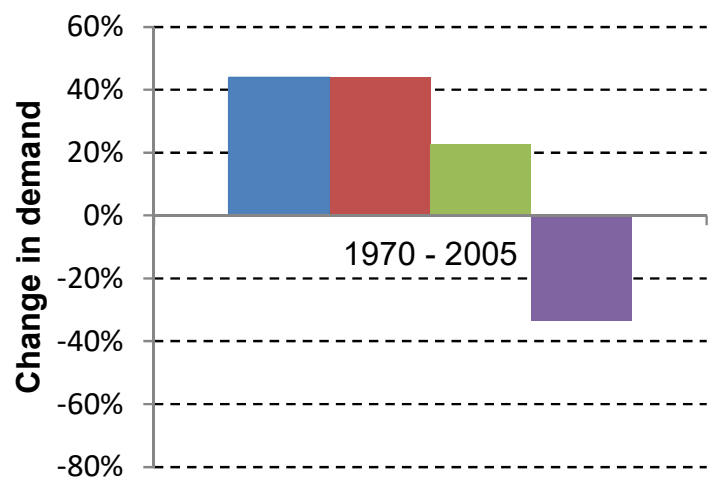

UK

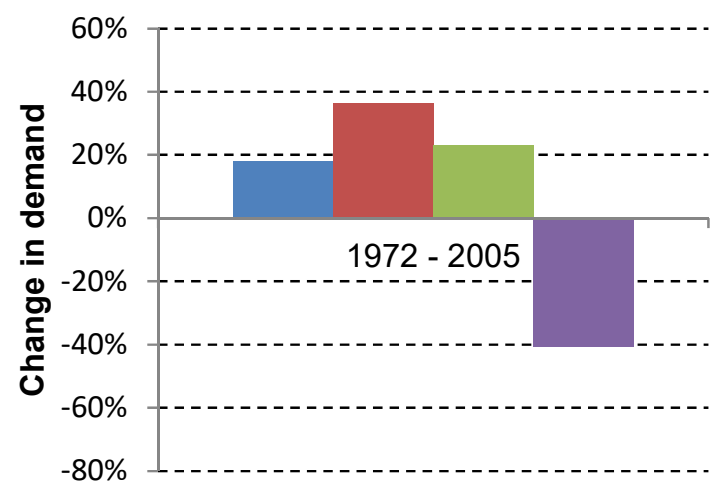

Figure 2 : Index Decomposition of residential sector energy use for space and water for the period from 1970 to 2005. 


\section{FRANCE}

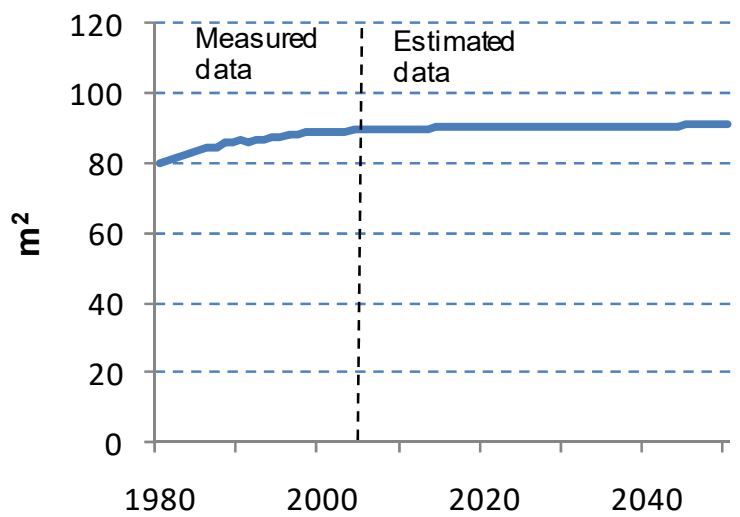

SWEDEN

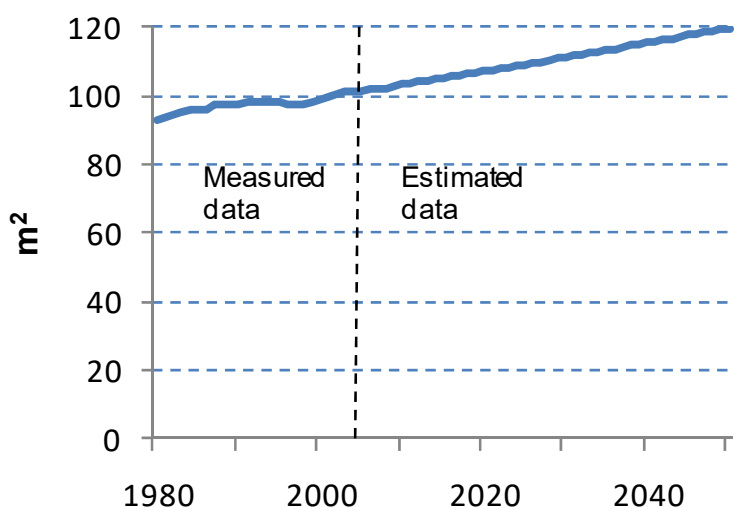

ITALY

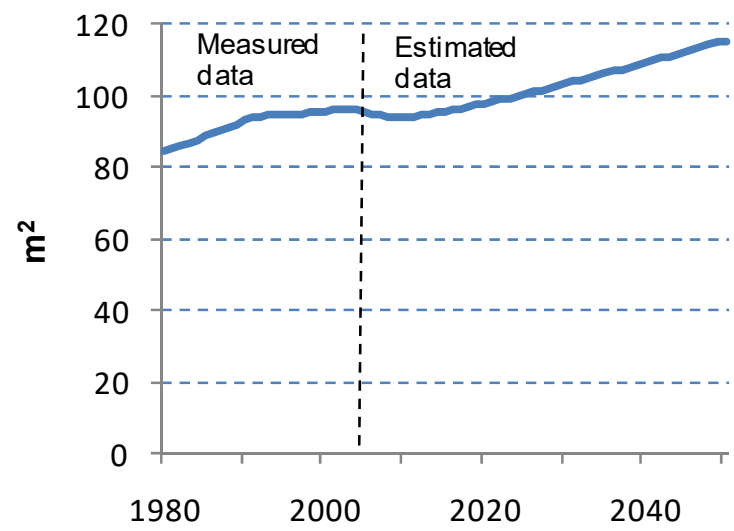

UK

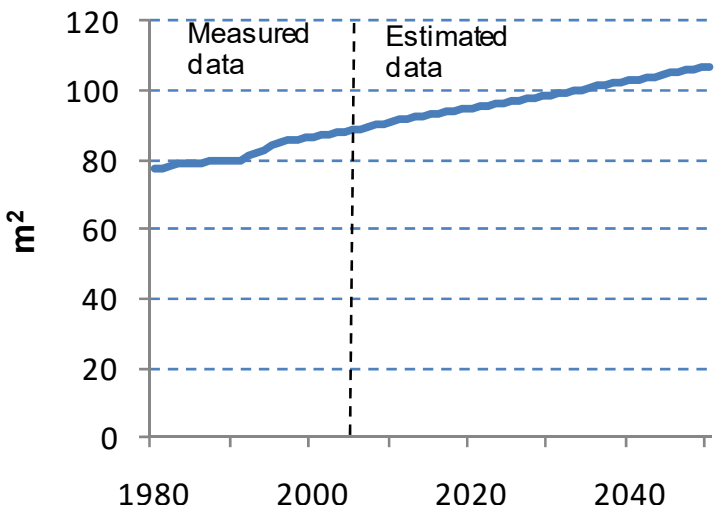

Floor Area per Household

Figure 3 : Scenarios for Floor Area per Household, $S_{t}$, from 2006 to 2050. 
FRANCE

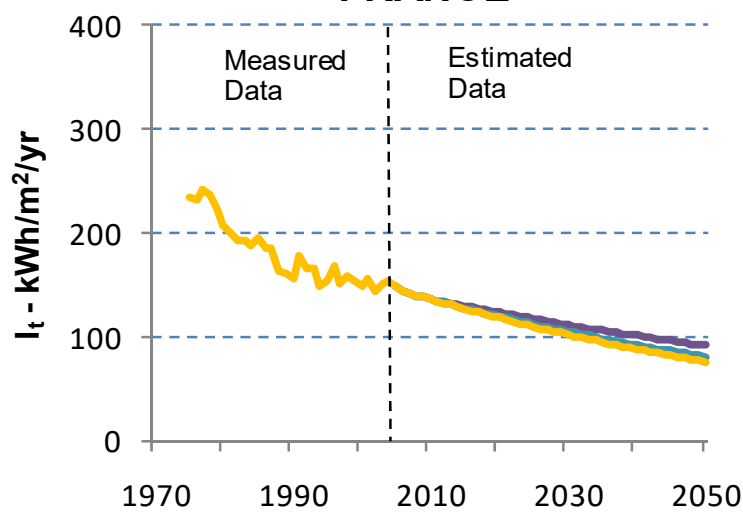

\section{SWEDEN}

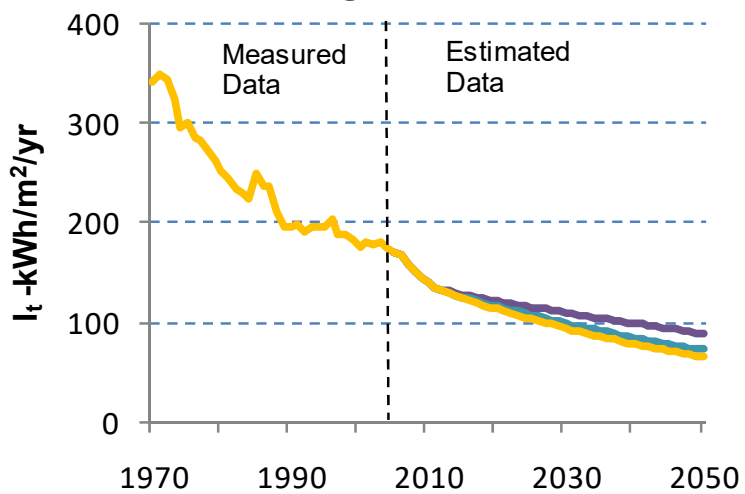

ITALY
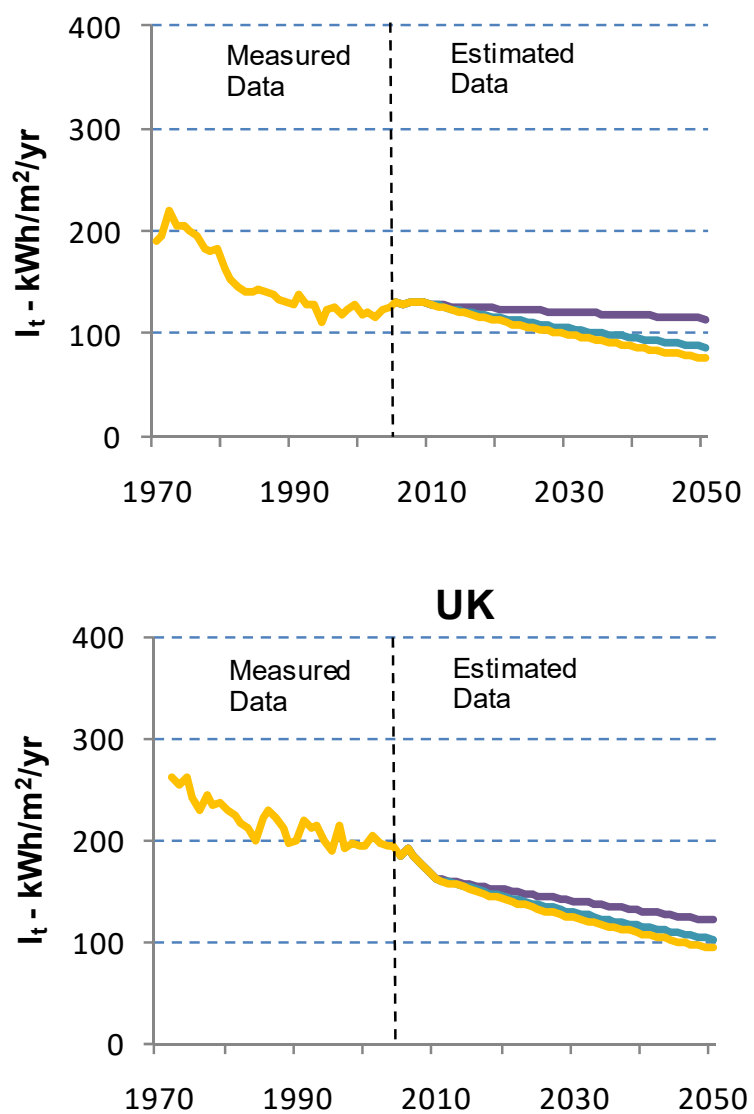

Annual Price Change: $-0 \%-2 \%-3 \%$

Figure 4 : Scenarios for unit consumption, $l_{t}$, from 2006 to 2050. 
FRANCE

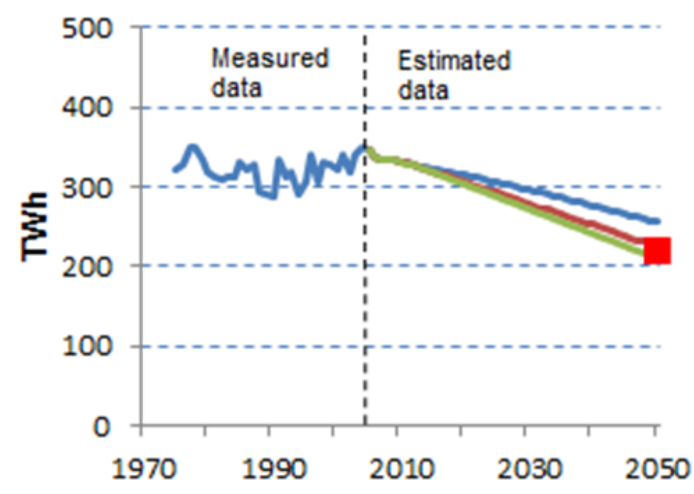

SWEDEN

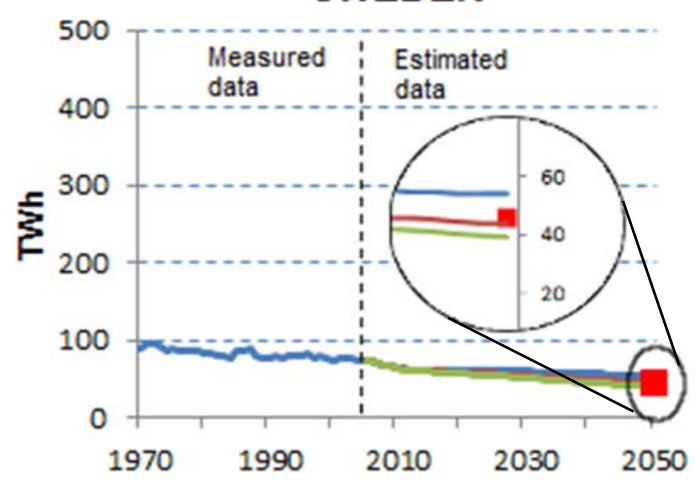

ITALY

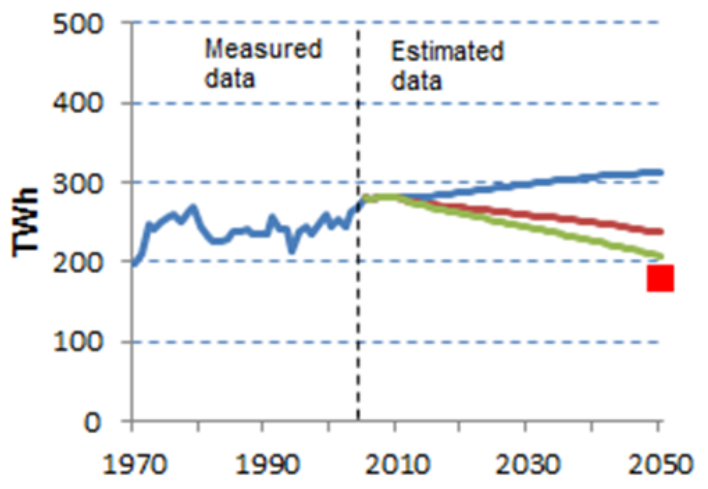

UK

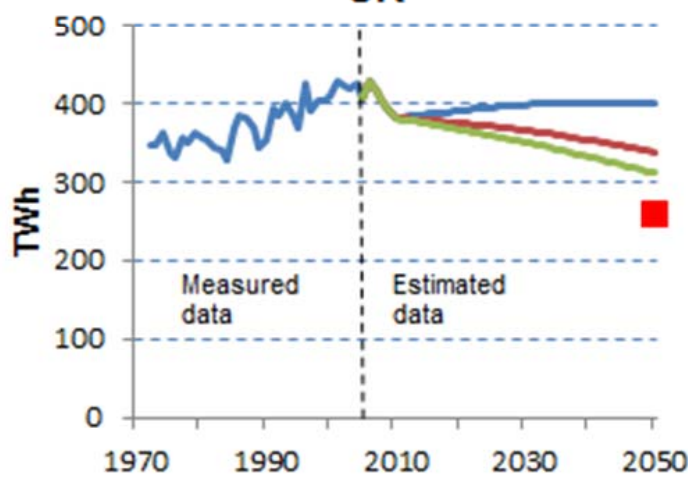

Annual Price Change

$-0 \%-2 \%-3 \% \quad$ - $1 \%$ compound annual savings 2006 to 2050 target

Figure 5 : Scenarios for total energy demand for space and water heating, $E_{t}$, from 2006 to 2050. 
FRANCE
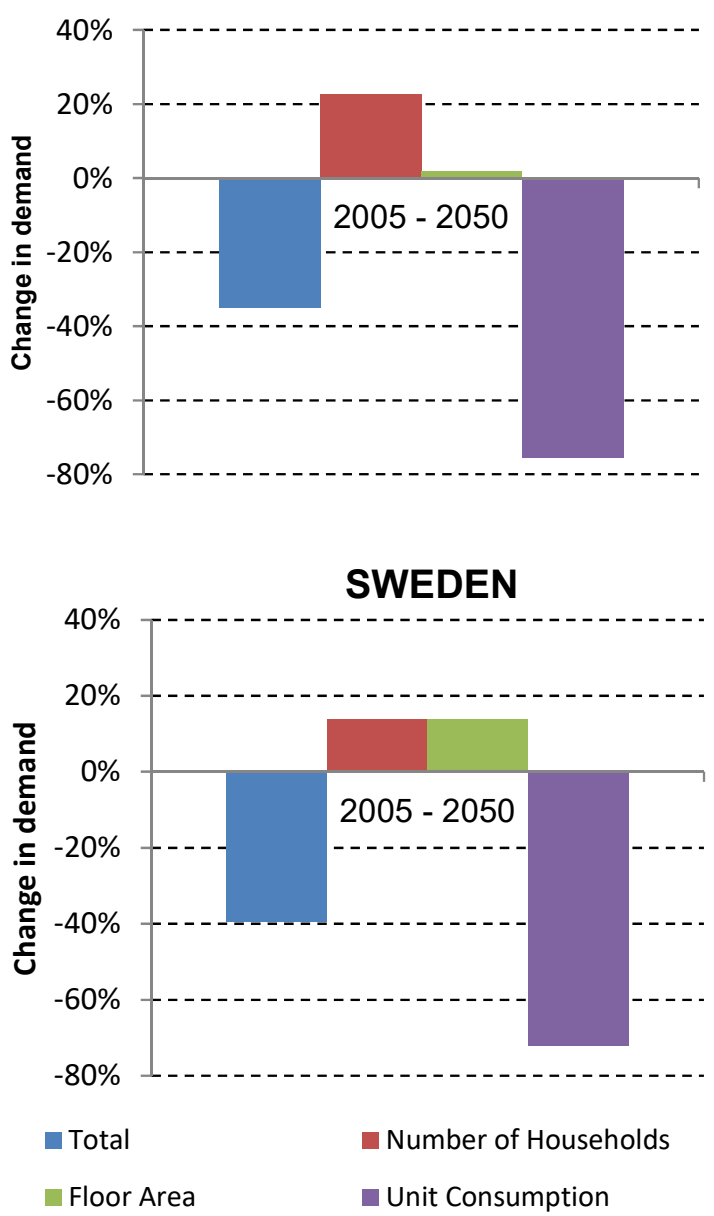

ITALY

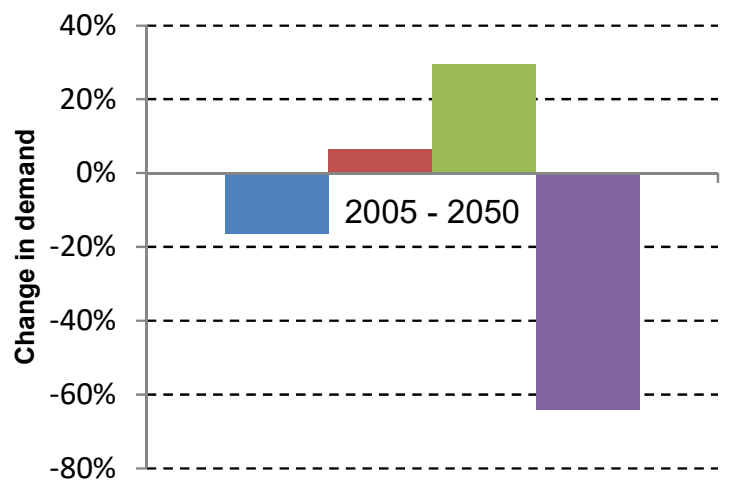

UK

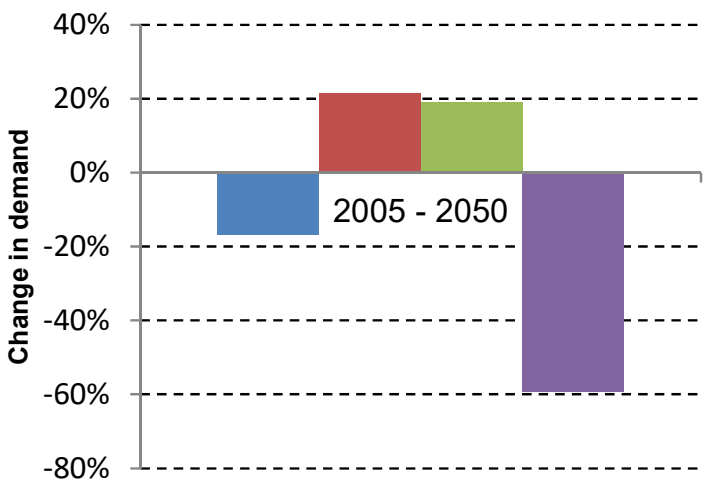

Figure 6 : Index Decomposition of residential sector energy use for space and water heating in $2 \%$ annual price increase scenario for the period from 2005 to 2050. 


\section{TABLES 1 to A.7}

Table 1 : Average number of persons per household in 2005.

\begin{tabular}{|l|l|}
\hline France & 2.3 \\
\hline Italy & 2.6 \\
\hline Sweden & 2.1 \\
\hline UK & 2.4 \\
\hline
\end{tabular}

Table 2 : ARDL Model of floor area per household ${ }^{\mathrm{a}}$.

\begin{tabular}{|l|l|l|l|l|}
\hline Floor Area per household & \multicolumn{1}{|c|}{ France } & \multicolumn{1}{c|}{ Italy } & \multicolumn{1}{c|}{ Sweden } & \multicolumn{1}{c|}{ UK } \\
\hline$\gamma_{0}$ (Constant) & 0.27 & 0.28 & 1.06 & 0.25 \\
\hline$\lambda$ (Lag Floor Area) & $0.94^{* * *}$ & $0.84^{* * *}$ & $0.54^{* * *}$ & $0.90^{* * *}$ \\
\hline$\beta_{1}$ (Income) & 0.00049 & $0.045^{* *}$ & $0.090^{*}$ & 0.021 \\
\hline Long-run Income & 0.0081 & 0.29 & 0.20 & 0.21 \\
\hline Adjusted $\mathrm{R}^{2}$ & 0.99 & 0.99 & 0.91 & 0.99 \\
\hline F-test statistic & 1431 & 1299 & 27 & 1710 \\
\hline Durbin h statistic & 0.48 & 0.57 & 0.58 & 0.98 \\
\hline Degrees of freedom & 20 & 19 & 7 & 20 \\
\hline
\end{tabular}

${ }^{\text {a }}$ The input data for France, Italy and the UK are from 1980 to 2005 and for Sweden they are from 1980 to 1992. The Durbin h statistics used to test for Serial Correlation are also presented. The addition of at least one lag was necessary for each country to eliminate serial correlation. Using the Doornik-Hansen test the distribution of residuals was found to be normal for the French, Swedish and UK models. Asterisk denote significance using heteroscedastic robust standard errors at $* 10 \%, * * 5 \%$ and $* * * 1 \%$ level of significance.

Table 3 : ARDL Model of Unit Consumption ${ }^{\text {a }}$

\begin{tabular}{|l|l|l|l|l|}
\hline Unit Consumption & \multicolumn{1}{c|}{ France } & \multicolumn{1}{c|}{ Italy } & \multicolumn{1}{c|}{ Sweden } & \multicolumn{1}{c|}{ UK } \\
\hline$\alpha_{0}$ (Constant) & 9.04 & 4.91 & 14.10 & 20.49 \\
\hline$\alpha_{1}$ (Trend) & $\mathbf{- 0 . 0 0 3 5} * *$ & $\mathbf{- 0 . 0 0 1 1}$ & $-0.0053^{* *}$ & $-0.0072^{* * *}$ \\
\hline$\varphi(\mathrm{Lag})$ & $\mathbf{0 . 6 4} * * *$ & $\mathbf{0 . 5 9} * * *$ & $0.49^{* * *}$ & 0.012 \\
\hline$\beta_{2}$ (Price) & $-0.060^{*}$ & $-0.14^{* * *}$ & $-0.14^{* * * *}$ & $-0.21^{* * *}$ \\
\hline$\beta_{3}$ (HDD) & $0.00011^{* * *}$ & 0.00013 & $0.000076^{* * *}$ & $0.00021^{* * *}$ \\
\hline Long-run Price & $\mathbf{- 0 . 1 7}$ & $\mathbf{- 0 . 3 5}$ & -0.27 & -0.21 \\
\hline Adjusted $\mathrm{R}^{2}$ & 0.98 & 0.95 & 0.98 & 0.94 \\
\hline F-test statistic & 313 & 147 & 314 & 105 \\
\hline Durbin h statistic & 1.23 & 1.39 & 1.30 & 0.76 \\
\hline Degrees of freedom & 24 & 30 & 30 & 28 \\
\hline
\end{tabular}

${ }^{a}$ The input data for Italy and Sweden are from 1970 to 2005, those for France are from 1975 to 2005, and those for the UK are from 1973 to 2005. One autoregressive lag was needed to eliminate serial correlation for Italy, Sweden, and the UK, while for France one distributed lag of HDD and one autoregressive lag were needed. Using the Doornik-Hansen test the distribution of residuals was found to be normal for the Italian, Swedish and UK models. Asterisk denote significance using heteroscedastic robust standard errors at $* 10 \%, * * 5 \%$ and $* * * 1 \%$ level of significance. Bold font denotes multicolinear variables. 
Table A.1 : Results of ADF unit root tests of stationarity on the time series data in levels.

\begin{tabular}{|c|c|c|c|c|c|}
\hline STATIONARITY & $\begin{array}{c}\text { Unit Consumption } \\
\left(\mathrm{kWh} / \mathrm{m}^{2}\right)\end{array}$ & $\begin{array}{l}\text { Price (National } \\
\text { Currency/MWh) }\end{array}$ & HDD & $\begin{array}{c}\text { Income (National } \\
\text { Currency /Capita) }\end{array}$ & $\begin{array}{c}\text { Floor Area } \\
\left(\mathbf{m}^{2} / \text { household }\right)\end{array}$ \\
\hline France (1975) & No $(2.6) 0$ & No (2.1) 1 & Yes (3.6) 0 & No $(2.5) 1$ & No $(0.4) 0$ \\
\hline Italy (1970) & No (1.3) 0 & No (2.0) 0 & Yes (6.2) 0 & No (1.3) 0 & No $(0.8) 1$ \\
\hline Sweden (1970) & No $(2.1) 0$ & No $(1.8) 0$ & Yes (3.9) 0 & Yes (3.4) 1 & No $(2.1) 0$ \\
\hline UK (1972) & Yes (4.3) 0 & No (3.0) 1 & Yes (4.1) 0 & Yes (4.0) 1 & No $(1.8) 0$ \\
\hline
\end{tabular}

Table A.2 : Results of ADF unit root tests of stationarity on the first differences of the time series data.

\begin{tabular}{|l|c|c|c|c|c|}
\hline $\begin{array}{c}\Delta \\
\text { STATIONARITY }\end{array}$ & $\begin{array}{c}\Delta \text { Unit Consumption } \\
\left(\mathbf{k W h} / \mathbf{m}^{2}\right)\end{array}$ & $\begin{array}{c}\Delta \text { Price (National } \\
\text { Currency } / \mathbf{M W h})\end{array}$ & $\Delta$ HDD & $\begin{array}{c}\Delta \text { Income (National } \\
\text { Currency } / \text { Capita })\end{array}$ & $\begin{array}{c}\Delta \text { Floor Area } \\
\left(\mathbf{m}^{2} / \mathbf{h o u s e h o l d )}\right.\end{array}$ \\
\hline France (1975) & Yes (4.7) 1 & Yes (3.4) 0 & -- & Yes (3.9) 0 & Yes (5.6) 1 \\
\hline Italy (1970) & Yes (5.6) 1 & Yes (4.4) 1 & -- & Yes (4.3) 0 & Yes (3.7) 0 \\
\hline Sweden (1970) & Yes (6.9) 0 & Yes (6.0) 0 & -- & -- & Yes (4.2) 1 \\
\hline UK (1972) & -- & Yes (3.7) 0 & -- & -- & Yes (4.7) 0 \\
\hline
\end{tabular}

Table A.3 : Cointegration vector coefficients for floor area per household.

\begin{tabular}{|l|c|c|c|c|}
\hline Floor Area per dwelling & France & Italy & Sweden & UK \\
\hline$\gamma_{0}$ (Constant) & 2.42 & 0.21 & 1.95 & 2.57 \\
\hline$\beta_{1}$ (Income) & 0.21 & 0.46 & 0.22 & 0.20 \\
\hline Adjusted $\mathrm{R}^{2}$ & 0.84 & 0.95 & 0.45 & 0.93 \\
\hline F-test statistic & 133 & 496 & 11 & 356 \\
\hline
\end{tabular}

Table A.4 : Results of ADF unit root tests of stationarity on the errors from the cointegration vector regression for floor area per household shown in Table A.3.

\begin{tabular}{|l|c|c|c|c|}
\hline$\Delta$ error $(\boldsymbol{e})$ & France & Italy & Sweden & UK \\
\hline Constant & -- & -- & -- & -- \\
\hline Lag error $(e)$ & $-0.15(2.5)$ & $-0.32(2.3)$ & $-0.60(3.7)$ & $-0.18(3.0)$ \\
\hline Lag $\Delta$ error $(\mathrm{e})$ & $0.65(4.8)$ & -- & $0.49(2.9)$ & $0.74(5.6)$ \\
\hline
\end{tabular}

Table A.5 : Cointegration vector coefficients for unit consumption.

\begin{tabular}{|l|c|c|c|c|}
\hline Unit Consumption & France & Italy & Sweden & UK \\
\hline$\alpha_{0}$ (Constant) & 25.29 & 22.43 & 31.34 & 21.73 \\
\hline$\beta_{2}$ (Price) & -0.10 & -0.22 & -0.25 & -0.23 \\
\hline$\beta_{3}$ (HDD) & 0.00031 & 0.00019 & 0.000090 & 0.00020 \\
\hline$\alpha_{1}$ (Trend) & -0.010 & -0.0082 & -0.012 & -0.0077 \\
\hline Adjusted ${ }^{2}$ & 0.97 & 0.90 & 0.97 & 0.94 \\
\hline F-test statistic & 327 & 101 & 337 & 161 \\
\hline
\end{tabular}


Table A.6 : Results of ADF unit root tests of stationarity on the errors from the cointegration vector regression for unit consumption shown in Table A.5.

\begin{tabular}{|l|c|c|c|c|}
\hline$\Delta$ error $(\boldsymbol{e})$ & France & Italy & Sweden & UK \\
\hline Constant & -- & -- & -- & -- \\
\hline Lag error $(e)$ & $-0.41(2.7)$ & $-0.47(3.25)$ & $-0.54(3.57)$ & $-0.89(5.0)$ \\
\hline
\end{tabular}

Table A.7 : Results of the VIF tests carried out on the ARDL model of unit consumption to check for multicolinearity.

\begin{tabular}{|lr|lr|lr|lr|}
\hline France & \multicolumn{1}{|l|}{ VIF } & Italy & VIF & Sweden & VIF & UK & VIF \\
\hline Price & 1.25 & Price & 2.96 & Price & 6.55 & Price & 1.67 \\
Trend & $\mathbf{1 2 . 2 1}$ & Trend & 7.73 & Trend & $\mathbf{1 4 . 4 3}$ & Trend & 7.95 \\
HDD & 2.47 & HDD & 2.82 & HDD & 1.33 & HDD & 1.64 \\
Lag & $\mathbf{3 0 . 4 4}$ & Lag & 9.06 & Lag & $\mathbf{2 4 . 7 9}$ & Lag & 5.98 \\
Lag HDD & 9.85 & & & & & & \\
\hline
\end{tabular}




\section{FIGURE CAPTIONS}

Figure 1 : Indices of time series of Unit Consumption for Space and Water Heating (I), energy prices (P), and Heating Degree Days (HDD) for 1970 to 2005.

Figure 2 : Index Decomposition of residential sector energy use for space and water for the period from 1970 to 2005.

Figure 3 : Scenarios for Floor Area per Household, $S_{t}$, from 2006 to 2050.

Figure 4 : Scenarios for unit consumption, $I_{t}$, from 2006 to 2050.

Figure 5 : Scenarios for total energy demand for space and water heating, Et, from 2006 to 2050.

Figure 6 : Index Decomposition of residential sector energy use for space and water heating in $2 \%$ annual price increase scenario for the period from 2005 to 2050. 


\section{TABLE CAPTIONS}

Table 1 : Average number of persons per household in 2005.

Table 2 : ARDL Model of floor area per household ${ }^{\mathrm{a}}$.

(footnote to Table 2)

${ }^{a}$ The input data for France, Italy and the UK are from 1980 to 2005 and for Sweden they are from 1980 to 1992. The Durbin h statistics used to test for Serial Correlation are also presented. The addition of at least one lag was necessary for each country to eliminate serial correlation. Using the Doornik-Hansen test the distribution of residuals was found to be normal for the French, Swedish and UK models. Asterisk denote significance using heteroscedastic robust standard errors at $* 10 \%, * * 5 \%$ and $* * * 1 \%$ level of significance.

Table 3 : ARDL Model of Unit Consumption ${ }^{\mathrm{a}}$.

(footnote to Table 3)

a The input data for Italy and Sweden are from 1970 to 2005, those for France are from 1975 to 2005, and those for the UK are from 1973 to 2005. One autoregressive lag was needed to eliminate serial correlation for Italy, Sweden, and the UK, while for France one distributed lag of HDD and one autoregressive lag were needed. Using the Doornik-Hansen test the distribution of residuals was found to be normal for the Italian, Swedish and UK models. Asterisk denote significance using heteroscedastic robust standard errors at * $10 \%,{ }^{*} 5 \%$ and $* * * 1 \%$ level of significance. Bold font denotes multicolinear variables.

Table A.8 : Results of ADF unit root tests of stationarity on the time series data in levels.

Table A.2 : Results of ADF unit root tests of stationarity on the first differences of the time series data.

Table A.3 : Cointegration vector coefficients for floor area per household.

Table A.4 : Results of ADF unit root tests of stationarity on the errors from the cointegration vector regression for floor area per household shown in Table A.3.

Table A.5 : Cointegration vector coefficients for unit consumption.

Table A.6 : Results of ADF unit root tests of stationarity on the errors from the cointegration vector regression for unit consumption shown in Table A.5.

Table A.7 : Results of the VIF tests carried out on the ARDL model of unit consumption to check for multicolinearity. 